\title{
A CAPACIDADE DIAGNÓSTICA DO PROFESSOR DE EDUCAÇÃO INFANTIL: UM CAMINHO PARA O CONHECIMENTO DA TERAPIA OCUPACIONAL
}

\section{MARIA CECÍLIA LEITE DE MORAES}

Tese de Doutorado apresentada ao Departamento de Saúde Materno-Infantil da Faculdade de Saúde Pública da Universidade de São Paulo para obtenção do Grau de Doutor.

Área de Concentração: Materno-Infantil

Orientador: Prof. Dr. Paulo Rogério Gallo

Co-Orientador:Prof. Dr. Fernando Lefèvre

São Paulo 2002

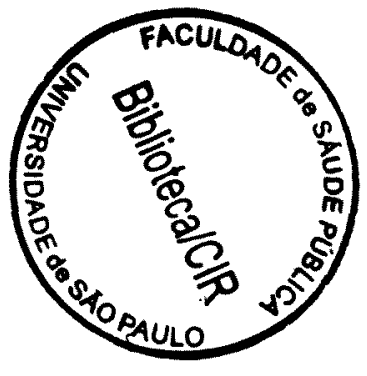


Autorizo, exclusivamente para fins acadêmicos e científicos, a reptoducto total ou parcial desta tese, por processos fotocopiadores.

Assinatura:

Dala:

$42278 / 2002$ dre 


\section{DEDICO ESTE TRABALHO}

aos meus pais Renato e Sonia pela referência de vida;

aos meus irmãos Ana Maria e Renato pela amizade;

aos meus sobrinhos Olyvia. Thiago e Felippe pela continuidade;

ao Carlos (Cha) pela cumplicidade

Com amor

Cecilia 
"Os homens não são somente eles, são também a região onde nasceram, a fazenda ou o apartamento da cidade onde aprenderam a andar, os brinquedos que brincaram em crianças, as lendas que ouviram dos mais velhos, a comida que se alimentaram, as escolas que freqüentaram, os esportes em que se exercitaram, os poetas que leram e o Deus em que acreditaram."

Sommerset Maughan - "O fio da navalha" 


\section{AGRADECIMENTOS}

Ao Prof. Dr. Paulo Rogério Gallo que pela presença constante, discussões proficuas, compreensão e amizade, fez seu trabalho de orientador transformar-se em uma parceria feliz, saudável e duradoura;

Ao Prof. Dr. lernando Lefèvre que por seu tempo, disponibilidade e generosidade em compartilhar sabedoria tornou-se um sócio majoritário nesta produção;

À Prof. Dra. Keiko Ogzura Buralli (saudades...) pela pertinência das sugestões, pela vontade de colaborar, por ter estado por perto;

À Prof. Dra. Augusta Thereza de Alvarenga pela contribuição;

Aos queridissimos: Iara Aparecida de Macedo, Leandro Iirmino Cleto e Meirizilda Soares Souza pela cooperação sempre;

Aos funcionários da Biblioteca da Faculdade de Saúde Publica/USP, em especial a senhora Maria Lúcia F. de Faria Ferraz, pela gentileza;

À minha cunhada Elaine Cristina dos Santos Moraes pelo cuidadoso trabalho na transcrição das fitas;

À professora Wanderléia Cristina dos Santos, meu apreço pela zelosa revisão do português;

À doce senhora Carolina Siqueira Ventura pelo trabalho de tradução; 
Ã senhora Ivany Abranches Pares de Oliveira, sinceros agradecimentos pela formatação final do trabalho;

Á senhora Sonia Maria Emigdio Silva por não ter me deixado desistir;

Aos amigos do $\mathrm{CDH}$ por ter me iniciado nesta carreira de pesquisar, e continuar comigo, mesmo de longe, nesta tarefa;

Ás senhoras Silvana Pires de Azevedo Kuhlmann, Cristina de Oliveira e Carla Braz por me "emprestar" horas para a organização final deste trabalho;

À professora Magali de Oliveira Barros por ter me ajudado a chegar na secretaria de educação do município de Taboão da Serra;

Ao secretário de educação do município de Taboão da Serra, professor .João Medeiros por ter consentido que a pesquisa fosse realizada;

Aos funcionários da Secretaria de Educação do Município de Taboão da Serra, com carinho especial a assessora Ana Maria de Silvio Cotellessa por ter me ajudado a chegar até as escolas;

Aos diretores das escolas municipais de educação infantil de Taboão da Serra por me abrir suas portas;

Ao professor Vanderlei Carlos "Branca" Severiano pelo folego;

Por último, o meu melhor para as protagonistas deste trabalho, as professoras entrevistadas, pelos depoimentos comoventes, pela confiança, pela grandeza. 


\section{RESUMO}

O presente trabalho teve como objetivo primeiro identificar a percepção do professor da escola de educação infantil sobre o aluno considerado, sob sua ótica, "diferente" do grupo, e conhecer o tipo de atuação do professor em relação a este aluno. Outro aspecto contemplado neste trabalho foi divisar o conhecimento do professor da escola de educação infantil acerca da Terapia Ocupacional e suas funções.

Para tais intentos optou-se por um estudo de corte qualitativo utilizando como instrumental a Análise do Discurso do Sujeito Coletivo (Lefevre, 1999). A pesquisa foi feita junto a trinta professoras de pré-escola pertencentes a rede pública de ensino do Município de Taboão da Serra.

A investigação trouxe informações bastante significativas destacando-se: a diversidade de percepção/conceituação sobre o que é uma criança "diferente", a complexidade nas abordagens quando da presença da criança "diferente" e o desconhecimento sobre a Terapia Ocupacional e suas funções.

De posse destas considerações salienta-se a importância de continuidade do trabalho tanto para a contribuição no processo de formação do professor de educação infantil nas diferenças observáveis no aluno, como no tocante a divulgação do trabalho da Terapia Ocupacional junto a estes. 
Cabe o destaque ao papel e função do professor da escola de educação infantil no que tange o desenvolvimento/aprendizagem da criança pequena. Constata-se que o papel do professor da escola de educação infantil deve incorporar formas de ensino não convencionais, do ponto de vista da cultura, um trabalho permeado pela flexibilidade e não somente na rotina estabelecida. 


\begin{abstract}
The present work aimed to identify the primary school teacher's perception of the student considered, in his/her view, "different" from the group, and to investigate the teacher's attitudes in relation to this student. Another aspect that was focused by this study was the primary school teacher's knowledge of Occupational Therapy and its functions.
\end{abstract}

To accomplish the objectives mentioned above, a qualitative study was carried out by means of the Collective Subject Discourse Analysis (Lefèvre, 1999). The research was conducted with thirty primary school teachers belonging to public schools in the municipality of Taboão da Serra, state of São Paulo.

The investigation provided significant data concerning: the diverse perceptions/conceptualizations of what a "different" child is; the complexity of the approaches when a "different" child is present; and the lack of knowledge relating to Occupational Therapy and its functions.

In light of this, the study emphasizes the importance of the continuity of the work, both to the process of education of the primary school teachers regarding observable differences in the student, and to familiarize them with Occupational Therapy. 
The study highlights the role and function of the primary school teacher in the small child's development/ learning. It is concluded that the primary school teacher's role must incorporate unconventional teaching forms from the point of view of culture, a work that is pervaded by flexibility and cannot be limited to the established routine. 


\section{ÍNDICE}

Resumo

Summary

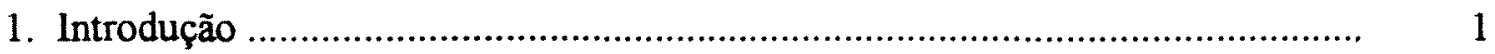

1.1 Um passeio pela história da Terapia Ocupacional ............................... 1

1.2 Era uma vez uma escola de educação infantil ou uma creche? Uma 6 creche ou uma escola de educação infantil?

1.3 A saúde escolar como campo de atuação a ser explorado pelo terapeuta 16 ocupacional

2. Objetivos

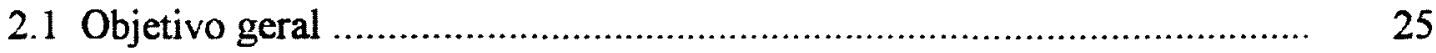

2.2 Objetivos especificos....................................................................... 25

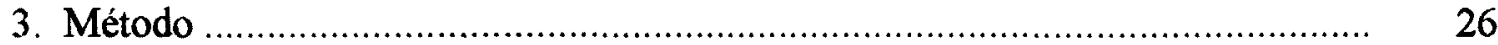

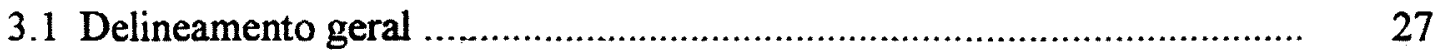

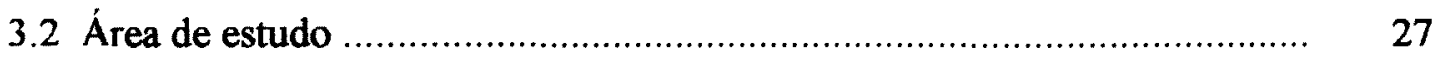

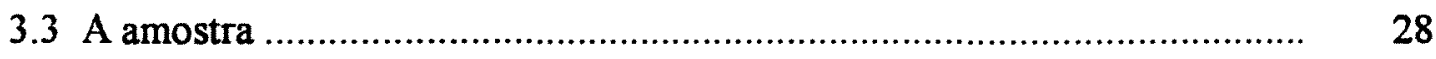

3.4 População de estudo ......................................................................... 29

3.5 Período de estudo .......................................................................... 29

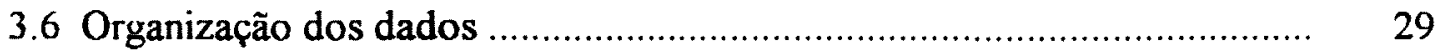

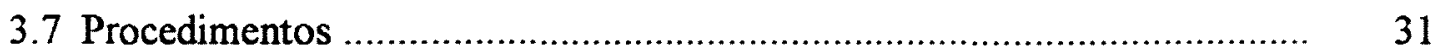

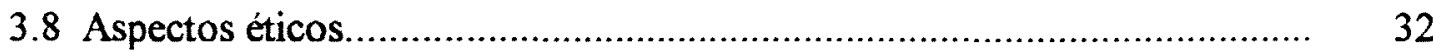

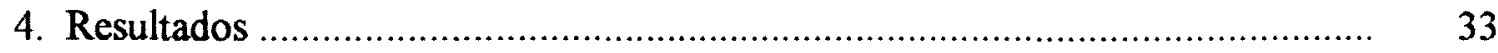

4.1 Uma foto do professor de educação infantil....................................... 33

4.2 Uma jornada pelo pensamento do professor de educação infantil ............ 37

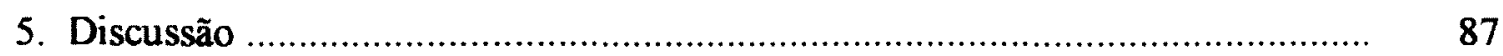

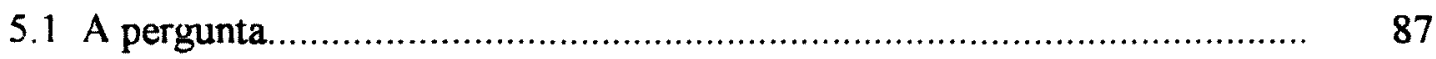

5.2 Notas sobre o diferente.................................................................... 88

5.3 Comentando os achados .................................................................... 91

6. Considerações finais ...................................................................... 104 
7. Referências bibliográficas.

Anexos

Anexo 1 - Questionário/Entrevista

Anexo II - Manual da Entrevista

Anexos III - Ficha da Escola

Anexo IV - Manual da Ficha da Escola

Anexo V - Termo de Consentimento

Anexo VI - Autorização para acesso aos Professores

Anexo VII - Termo de Compromisso Ético 


\section{1 - INTRODUÇÃO}

\section{1- Um passeio pela história da Terapia Ocupacional}

Desde épocas remotas, a prática de atividades fisicas, no tempo disponivel pelas pessoas, tem sido valorizada e reconhecida como um meio para a promoção de saúde e, também, importante método terapêutico. HOPKINS (1978) cita que os chineses, já em 2600 AC, tratavam a "doença" como fruto da inatividade orgânica e, sob esta perspectiva, trabalhavam o corpo fisico em busca da cura e da promoção de saúde. Sócrates e Platão realçavam a importância da associação entre o status fisico e a sanidade mental. É aforismo grego o preceito "mens sana in corpore sano". Aristóteles, apregoava por exemplo, que a educação do corpo deveria preceder a do intelecto. Hipócrates, no ano de 359, assim como Galeno recomendavam exercícios a seus pacientes com o propósito de recuperação. Estes pensamentos fazem parte da gênese da Terapia Ocupacional. No século V, na África, Caius Aurelius desenvolveu um programa para os convalescentes no qual eram preconizadas atividades como: andar, leituras, teatro e viagens.

No século XVI, em 1752, nos Estados Unidos da América, mais precisamente no Hospital da Pensilvânia, registrou-se um dos primeiros momentos da prática institucionalizada da Terapia Ocupacional. Atividades manuais eram prescritas como método terapêutico para os pacientes submetidos a tratamento mental. O responsável por este trabalho, foi o médico Benjamin Rush. Este indicava para os doentes atividades 
especificas, exercicios e diversão; todos como procedimentos terapêuticos. Rush, afirmava que estas atividades poderiam atuar sobre os corpos e as mentes dos pacientes.

No século XVII, na França, Philippe Pinel no Asilo para Insanos de Bicêtre, também empregava a terapia ocupacional como método de tratamento. No ano de 1801 , Pinel publicou um trabalho onde abordava sobre a qualidade dos exercícios físicos e das atividades manuais como método terapêutico (HOPKINS, 1978).

No percurso histórico da profissão, destaca-se que as duas guerras mundiais foram responsáveis por grandes impulsos da Terapia Ocupacional. Na Primeira Guerra Mundial, estava associado às mutilações ocorridas, quando se pensava com mais acuidade na Terapia Ocupacional voltada para a recuperação, enfatizando minorar as incapacidades físicas e os problemas psiquiátricos dos soldados. Na Segunda Guerra, ocorreu face a necessidade de incorporar o grande número de incapacitados ao mercado de trabalho, considerando a ótica economicista da vantagem econômica (MOSEY,1979).

Entre o fim da década de 40 e início da década de 50, estabeleceu-se o reconhecimento de algumas profissões da área de saúde, com a instituição de "diplomas formais". Cristalizou-se a mudança do eixo vocacional; o trabalho missionário transformon-se em trabalho técnico-científico para a terapia ocupacional (LOPES, 1993/6) 
No Brasil, a Terapia Ocupacional, foi instituida a partir da necessidade de setores de psiquiatria e tisiologia. Isto ocorreu por volta da metade do século $\mathrm{XX}$, para compensar tanto o isolamento da vida doméstica, como o rompimento brusco dos pacientes com os hábitos e as relações sociais; introduziram-se atividades recreativas, de auto-cuidado, profissionalizantes e de conservação/ preservação do espaço institucional, com o claro propósito de ocupar os internos (SOARES, 1991).

As instituições precursoras do uso da "ocupação", foram o Hospital do Engenho de Dentro (RJ), Hospital do Juqueri (SP), Hospital de Barbacena (MG) e Hospital Colônia Juliano Moreira (PE).

A partir da década de trinta, houve uma "alteração" na orientação terapêutica no Brasil. Impôs-se como conseqüência da crise econômica internacional que atingiu a economia exportadora nacional, uma orientação contencionista do Estado sobre as politicas sociais; esta nova organização voltou-se para a industrialização e formação do monopólio econômico nacional. Desta forma, a rede pública hospitalar sofreu um corte de verbas, ao mesmo tempo que tomou-se, praticamente albergue de doentes e indigentes, vindos das cadeias públicas, sem condições para oferecer tratamento a doentes tuberculosos ou psiquiátricos (SOARES, 1991). Esta situação levou a uma estagnação no processo de implantação da Terapia Ocupacional como prática profissional. 
O mesmo autor, destaca que, na década seguinte, com a "redemocralização da sociedade" retomou-se o trabalho terapêutico. Este recomeço veio atrelado ao modelo de capital monopolista e associou-se com a especialização da ciência. É o nascimento de uma "nova ordem técnico-científica", na área de saúde, fundamentada em orientações teórico-práticas.

A partir da década de 60 , os terapeutas ocupacionais re-examinaram as repercussões de seus procedimentos no âmbito clínico e social de seus pacientes. Montaram-se "fori" de debates e oficinas experimentais onde foram discutidos e estudados a incorporação de orientações neurocomportamentais dentro da prática terapêutica. Ainda nesta época, nos Estados Unidos, montaram-se programas de pósgraduação em nível de mestrado, congregando profissionais de outras áreas, o que trouxe avanços significativos na pesquisa e metodologia da profissão. Este refinamento técnico-científico encorajou os terapeutas ocupacionais a envolverem-se com o exercício profissional desinstitucionalizado da prática clínica (HOPKNNS, 1978). Foi o momento da tecnização das atividades.

A primeira conseqüência imediata da tecnização da Terapia Ocupacional foi trabalhar-se sob a ótica reducionista, que privilegiou a redução do mundo empírico em seus diferentes fenômenos. Abre-se um parêntesis para explicar que na perspectiva reducionista, abdicou-se da totalidade, versatilidade e heterogeneidade, em favor da visão exclusiva unidimensional (SOARES, 1991). 
Este novo paradigma, no âmbito da saúde, incluiu os conceitos de biofísica, bioquímica e a perspectiva psicanalítica da psiquiatria, sendo que estes eram trabalhados de maneiras separadas e compartimentalizadas.

A Terapia Ocupacional passou a ser regida por duas correntes: uma fisica e uma mental. CARVALHO (1953) "dividiu" a Terapia Ocupacional em Reabilitação Física Pós-traumatismo e Terapia Ocupacional Psicológica, sendo que esta poderia ser "subdividida" em: Terapêutica Ocupacional Específica, Não Especifica ou Laborterápica ou seja, colocação de pacientes em empregos.

$\mathrm{O}$ atendimento dos problemas fisicos, trouxe à tona o modelo neurológico, relacionado ao binômio percepção e motricidade. Profissionais de diferentes áreas trouxeram significativos subsídios para a Terapia Ocupacional. Destacam-se neste "novo" enfoque Jean Ayres, terapeuta ocupacional que introduziu a abordagem do tratamento pela integração-sensorial; o casal Bobath que com seu modelo de terapia neuroevolutiva voltou-se, inicialmente, para pacientes portadores de paralisia cerebral; Rood com a técnica de estimulação sensorial e Frostig com técnicas de desenvolvimento perceptivo. No Brasil, no inicio da década de 70 , uma expressiva contribuição no âmbito da avaliação neurológica, que trouxe importantes repercussões para a terapia ocupacional, foi outorgada pelo médico Antonio LEFĖVRE (1972).

O atendimento neurológico em Terapia Ocupacional, tem como objetivo estimular o desenvolvimento sensório-perceptivo-motor. O caráter do atendimento 
acontece em nivel preventivo e nos tratamentos dos distúrbios de desenvolvimento, capacitando o indivíduo a desempenhar tarefas de auto-cuidado, educacionais e vida prática.

Nos dias de hoje, a atuação dos profissionais no Brasil, fora do setor estatal, limita-se ao tratamento das classes economicamente mais privilegiadas e às entidades filantrópicas, de caráter assistencialista, sendo aqui, ainda, "um trabalhador de caráter caritativo", reproduzindo, as ações de senhoras beneméritas (LOPES, 1993/6).

\section{2 - Era uma vez uma escola de educação infantil ou uma creche? Uma creche ou uma escola de educação infantil?}

Torna-se importante ressaltar que na literatura brasileira existe pouca diferenciação entre o termo creche e escola de educação infantil, o que acabou por dificultar o conhecimento da origem histórica desta última instituição no Brasil.

A educação infantil "latu senso" é concebida como a educação total que a criança recebe no periodo dos 0 aos 6 anos de idade. Esta especificidade educacional pode ser classificada de duas maneiras: educação informal e educação formal. Considera-se a educação infantil informal aquela realizada no âmbito doméstico ou nos espaços que circundam a casa, como por exemplo: quintais, ruas, parques, clubes, pracinhas, "playgrounds" e outros. A educação infantil formal é reconhecida como aquela desenvolvida em ambiente pedagógico especializado, podendo ser ainda, uma conjunção de ambas modalidades descritas: informal e formal (SOUSA, 1986). 
O conceito restrito da educação infantil diz respeito a atuação desenvolvida em estabelecimentos especializados com funções nitidamente pedagógicas, ou seja, instituições que apresentam objetivos educacionais (SOUSA, op.cit.).

A educação infantil nasceu entre os séculos XVII e XVIII quando instaurou-se, segundo ÁRIES (1981), o sentimento de infância; onde constatou-se que as crianças eram diferentes dos adultos e que traziam em sua essência necessidades próprias.

$\mathrm{Na}$ pedagogia tradicional, a escola fundamentava-se na transmissão de conhecimento e a escola de educação infantil vinculava-se mais às atividades lúdicas. De acordo com NASCIMENTO (2000), Fröbel, filósofo do periodo romântico, criador dos "kindergarten", valorizava a liberdade de expressão da natureza infantil por meio de brincadeiras livres e espontâneas, instituindo uma pedagogia que tinha como eixo a representação simbólica. Afirma-se, contudo, que as instituições de educação infantil não se limitavam aos jardins fröebelianos.

$\mathrm{Na}$ Europa, durante o século XVIII, surgiram instituições voltadas, principalmente, para as crianças abandonadas ou filhas de trabalhadores pobres. Estas instituições eram alternativas de cuidados e educação da criança pequena, tarefas que, até então, tinham seu desempenho restrito ao âmbito familiar. Os estabelecimentos de educação infantil foram revitalizados, no século XIX, por força da industrialização, urbanização e migração; e traziam abarcados a este novo contexto, de ordem urbano 
capitalista, a necessidade da guarda dos filhos dos trabalhadores. De modo geral, a familia viu com desconforto a oferta de educação fora do lar, sua função em orientar e educar seus filhos parecia ameaçado (NASCIMENTO, 2000).

SPITZ (1991) e BOWLBY (1984), em estudos realizados no pós-guerra, acerca dos possíveis impactos da institucionalização sobre o comportamento infantil, sustentavam que a privação materna prejudicava o desenvolvimento sadio da criança em seus primeiros anos. Considerando essa premissa, a escola de educação infantil seria uma saída para aquelas famílias que não poderiam oferecer educação em casa ou ainda, segundo LEFĖVRE (1994), um mal necessário, reforçando o aspecto que, na maioria dos casos, as crianças partiam para as instituições de educação infantil em função da necessidade, e não pela vontade das familias.

Hoje, pesquisas apontam que o apego e as primeiras relações afetivas do ser humano, construídas inicialmente com a mãe, podem ser ampliadas e que tanto o bebê como a criança pequena têm capacidade para estabelecer novos vínculos; sendo que esta teoria pode ser reforçada pelas experiências correntes ao longo da vida humana, onde é percebido, de maneira genérica, que a rede de relações continua sempre a se expandir. A escola faz parte desta rede relacional. Compreende-se, atualmente, que a tarefa de educação das crianças pequenas deve ser compartilhada entre familia e escola.

Visitando ainda as origens universais da educação infantil, segundo ROLLETECHALIER (1990), verificou-se que as mesmas estavam associadas a ablação da 
espontaneidade da criança, negação do prazer e ausência do contato corporal, com o objetivo de integrar rapidamente os pequenos à sociedade, cabendo aos pais o treinamento para que os filhos seguissem apenas normas (regras, leis) indicadas como necessárias para o bom desenvolvimento da criança durante a infância.

Assim, de acordo com ROLLET-ECHALIER (op. cit), a educação infantil nos anos 30 e 40 estava ligada a obediência e incorporava o discurso da saúde. Era intervencionista e correlacionava-se com os princípios da eugenia.

No Brasil, final do século XIX, isto é, no início da República, em São Paulo, as creches eram asilos infantis e tinham como função a guarda de crianças órfãs em regime de internato (SOUSA, 1986).

O mesmo autor relata que entre o final do século XIX e início da década de 20 as creches, os asilos e os jardins-de-infância eram instituições que prestavam serviços para as populações menos favorecidas, do ponto de vista econômico, com concepções assistencialistas.

O histórico da educação infantil em São Paulo mostra que tanto na década de 20 como na de 30 , os asilos infantis, as escolas maternais e os jardins-de-infância, a partir da terminologia empregada, assumiam significados diferentes separando-se segundo o tipo de população atendida, o que acarretou uma série de discriminações e preconceitos, com repercussões até os dias de hoje (SOUSA op.cit.). 
Nos anos 30, os jardins-de-infância eram subsidiados pelo governo e passaram a contar com professores em seus quadros. Os jardins-de-infância prestavam serviços de assistência médica, alimentar e educativa, priorizando as duas primeiras.

As escolas maternais foram instaladas para atender os filhos de operários tendo como objetivo buscar o desenvolvimento integral da criança, unindo o caráter pedagógico e o assistencial, diferenciando-os da função asilar. $O$ jardim-de-infância, com objetivos pedagógicos, destinava-se a prestar serviços às classes economicamente privilegiadas (SOUSA, op.cit.). Portanto, são duas terminologias voltadas para tipos de populações diferentes: maternais para filhos de operários e jardins-de-infância para a classe média e a elite.

No Brasil, a história da educação e da saúde encontram-se imbricadas. Até a década de 50 a saúde e a educação estavam dentro de um mesmo Ministério com ações muito ligadas. A Educação estava tomada por um olhar médico. Os programas da escola para a criança pequena priorizavam a lactação, vacinação, inspeção das condições de vida e higiene das crianças pobres, proteção do abandonado e inspeção médica. Estes programas justificavam a organização das crianças em creches e jardins-de infância (ROSSETTI-FERREIRA e colaboradores, 2000).

Destaca-se que desde 1889 fora criado o serviço de Higiene Escolar e na década de 20 os cursos de medicina passaram a contar com esta disciplina. Nesta mesma época, 
a Escola Normal "Caetano de Campos", em São Paulo, trazia em seu currículo a disciplina de puericultura, buscando mostrar aos alunos de magistério a técnica de como desenvolver hábitos de higiene entre seus futuros educandos (FERRIANI \& GOMES, 1997).

Na década de 40, o Estado, através do Departamento Nacional da Criança e Legião Brasileira de Assistência instrumentalizou-se, de maneira mais técnica, para o atendimento da criança. Os programas materno-infantis incorporaram, por meio de recursos educacionais, técnicas especificas e aprimoradas voltadas para os quesitos educação, saúde e assistência: (VIEIRA, 1988).

De forma ampla, até os anos 60 , os equipamentos de educação infantil eram uma resposta às exigências de mães trabalhadoras, que pretendiam ter um local de guarda e cuidados para seus filhos menores de sete anos de idade. Ressalta-se que estes estabelecimentos funcionavam nos locais de trabalho das mães. A preocupação maior era o controle sanitário, principalmente controle de contaminações e prevenção de doenças (VIEIRA, op.cit.).

No início dos anos 80, o Governo do Estado de São Paulo criou os Centros de Convivência Infantil. Também estes, foram criados em função de uma exigência do corpo de funcionários públicos estaduais, para que seus filhos na faixa etária entre zero e sete anos de idade fossem atendidos. Estes equipamentos foram desenhados sobre propostas educacionais (ROSSETI-FERREIRA e colaboradores, 2000). 
A Constituição de 1988 assumiu a educação infantil, isto é, o atendimento educacional dos zero aos seis anos de idade como Direito da criança, Dever do estado e Opção da familia (artigo 208, inciso IV).

Na Lei de Diretrizes e Bases da Educação Nacional (1996) a educação infantil tem como objetivo o desenvolvimento integral das crianças menores de sete anos de idade. A educação contempla fatores sociais, físicos, psicológicos, intelectuais e complementa-se com o suporte oferecido pela família e pela comunidade. Ressalta-se que este atendimento está vinculado ao sistema de ensino. Desta forma o atendimento do sujeito em idade de educação infantil, creche e jardim-de-infância é de responsabilidade da Secretaria de Educação (Lei 9.394/1996).

Percebe-se, ao longo da história da educação infantil, que a creche jamais foi reconhecida como um espaço privilegiado de educação e desenvolvimento, sendo apenas incorporada, muitas vezes, no sistema organizacional político e no cotidiano dos cidadãos como um lugar de guarda e alimentação de crianças oriundas das famílias trabalhadoras das classes mais populares. Tal fato é evidenciado, ainda hoje, quanto ao uso da própria terminologia creche, que ficou marcado como um lugar abrigo quase sempre público, localizado nas periferias carentes das grandes cidades.

Observa-se que em função das colocações explicitadas no parágrafo acima, existe ainda, na revisão da literatura muita confusão sobre os objetivos e as definições dos 
termos creche/escola de educação infantil. Diferentes autores apresentam variadas versões sobre este tema. MIALARET (1976) questionou a terminologia escola de educação infantil afirmando que tal termo induz a refletir sobre programa preparatório à escolarização formal.

Para ROSSETI-FERREIRA e colaboradores (2000) a denominação das instituições tende a se dar em função da faixa etária atendida: a creche é a instituição que atende as crianças de zero a três anos de idade e a escola de educação infantil as crianças de quatro a seis anos de idade.

Para KRAMMER (1988) a creche se diferencia da escola infantil pelo "iipo" de funcionamento, a creche tem horário integral e a escola de educação infantil "meio período". As duas instituições distinguem-se, ainda, por suas vinculações administrativas: a creche estaria associada a órgãos com características médicas ou assistenciais, e a escola de educação infantil ao sistema educacional.

ROSEMBERG e colaboradores (1985) discutem que a escola de educação infantil preocupa-se com a preparação para a entrada da criança no primeiro grau, quase nunca considerando ou atendo-se às questões da organização familiar que influenciam sobre a situação da criança pequena. A prática cotidiana do pesquisador permite afirmar que parte significativa do sistema educacional observa a criança que freqüenta a escola de educação infantil de maneira limitada, dando pouca significação aos aspectos do 
desenvolvimento infantil, que pareceriam não estar diretamente ligados ao futuro rendimento escolar das crianças.

Outro ponto relevante, de acordo com ROSEMBERG e colaboradores (op. cit.), seria que as atividades educativas que aparecem na escola de educação infantil quase sempre constituiriam uma preparação para a alfabetização, entendida exclusivamente como atividades com lápis e papel, geralmente exercícios sobre folhas impressas.

A ênfase no desenvolvimento cognitivo, preponderante nos anos 70 e seguinte, começou a abrir espaço para uma preocupação com os outros aspectos do desenvolvimento, ou seja, aspectos sócio-afetivos dos quais não poderia estar dissociado. Neste sentido, substituiu-se a concepção da criança de um vir a ser para compreendê-la como ator protagonista de seu desenvolvimento e aprendizagem, capaz de expressar seus sentimentos e necessidades.

Desde sempre a criança é um sujeito que participa e interage com a sociedade. $\dot{E}$ esta nova concepção que prima no Referencial Curricular Nacional de Educação Infantil, lançado pelo Ministério da Educação e Cultura em 1998, à semelhança de estudos e práticas em várias partes do Brasil e no mundo; e que se pretende, de forma abrangente, incorporar no sistema de educação brasileiro em vigor.

A nova concepção do Referencial Curricular Nacional de Educação Infantil discorre, também, sobre a importância da escola tornar-se mais inclusiva. Contudo um 
obstáculo a esta politica pública é a dificuldade de incorporar um sistema de apoio às necessidades dos alunos e professores. Se por um lado é possivel prever que uma politica expansionista do projeto educacional incorpore alunos de variados graus de desenvolvimento pedagógico, por outro é preciso subsidiar as instituições com profissionais capacitados, na sua formação, na intervenção dos problemas de desenvolvimento. Diante deste quadro observa-se um hiato entre a política da rede de educação infantil e a vontade política em contratar profissionais da rede técnica de apoio, entre eles, o terapeuta ocupacional. Assim, apesar dos avanços teóricos no àmbito da compreensão do processo da educação infantil mantêm-se, em diversos locais, a mesma prática de transferir ao professor a responsabilidade plena, inclusive da aprendizagem da criança.

Há um relativo consenso na literatura, admitido por ROSSETTI-FERREIRA e colaboradores (2000), de que as atividades desenvolvidas na escola de educação infantil, deveriam também, contemplar o registro e o acompanhamento do desenvolvimento das crianças, procedimento este que visaria ajudá-las em suas dificuldades antes que a aprendizagem fosse prejudicada. $O$ presente trabalho prioriza o conhecimento da percepção sobre este aspecto por parte dos educadores/professores de uma rede pública de educação infantil. As escolas particulares, para a classe média, obedecem de maneira geral, a outra lógica de ensino. Tal situação, foge do escopo deste trabalho. 


\section{3 - A saúde escolar como campo de atuação a ser explorado pelo terapeuta ocupacional}

Os limites sociais no campo de atuação profissional do terapeuta ocupacional deixam claro as potencialidades e as necessidades de ocupação de novos espaços de atuação profissional, sendo o campo da saúde escolar um deles, com trabalho junto as escolas de ensino fundamental e de educação infantil. Não se trata de focalizar escolas especiais mas, escolas comuns que recebem crianças provenientes dos mais variados contextos histórico-sociais envoltas em suas diferenças. Algumas dessas diferenças são decorrentes de varią̧̃es do desenvolvimento da criança, como por exemplo, os distúrbios de integração sensorial (AYRES, 1980), as disfunções cerebrais mínimas e um conjunto de danos neurológicos não evidentes (MORAES, 1995); que podem dificultar sua vida na escola de educação infantil e/ou ensino fundamental.

Dentro desta mesma perspectiva, o artigo de MAGALHÃES e colaboradores (1998) discute sobre a estreita relação entre pequenas anormalidades neurológicas, observadas no primeiro ano de vida, e o fracasso escolar.

Os contextos sócio-ambientais desfavoráveis, pobres em estimulos frente às necessidades sociais dominantes, contribuem para potencializar a variabilidade biológica, às vezes, compreendida como "problema". Variabilidade esta que pode não ser valorizada pelo entorno social até o momento em que a criança ingresse na escola. 
Segundo MULAS e colaboradores (1998), estas diferenças tornam-se visíveis e até contundentes na idade escolar.

Com incapacidades ou dificuldades de cumprirem as expectativas escolares e/ou sociais, as crianças começam a despertar a curiosidade e a preocupação dos professores. Segundo KEMMIS \& DUNN (1996) a preocupação dos educadores volta-se para a habilidade do aluno em desempenhar tarefas escolares, apesar dos mesmos não perceberem a natureza do problema do aluno. Deve ser enfatizado que existe pouco consenso entre os investigadores sobre o conceito na dificuldade de aprendizagem. Para MULAS e colaboradores (1998), o mais próximo seria uma discrepância entre capacidade potencial da criança e seu rendimento escolar.

SCHARTZMAN (1994), discute a distância entre os conceitos programáticos da escola e a vida real da criança. Aponta, ainda, o fato da dificuldade do professor em conhecer as peculiaridades de cada aluno, considerando principalmente, a sala de aula com muitas crianças. Quando certas diferenças ou peculiaridades são conhecidas, podem não ser relevadas. Outro fator a ser considerado, segundo ARAÚJO (1996), é que muitos educadores, em nossa sociedade, não convergem esforços para aprimorar a relação entre o método pedagógico e estado de maturidade ou prontidão da criança. Quer dizer: o como algo é ensinado/transmitido pelo professor e a capacidade da criança aprender/compreender. 
Destaca-se que, ainda hoje, no Brasil, a prática do ensino mostra o processo de inclusão como sendo de responsabilidade do aluno e sua família. $\mathrm{O}$ aluno com ou sem dificuldades deve adaptar-se a escola (COLLARES \& MOYSÉS, 1985; CARRARO, 1999). Na medida em que isto não ocorre, independentemente do tipo de problema, ele é colocado em salas de educação especial, com o claro objetivo de ser trabalhado de maneira diferenciada. Entretanto tal procedimento demonstra que este local acaba apenas por circunscrever a criança e suas dificuldades/diferenças/peculiaridades fora do habitat normal da escola (longe dos outros, não incomodando), separando-a do rotineiro e usual da instituição, com pouco ou nenhum beneficio (LEE e colaboradores, 1998; C.ARRARO, 1999).

Cabe citar que, de maneira geral, este procedimento atinge as crianças de escolas públicas e, normalmente, provenientes de classes menos favorecidas, onde serviços mais especializados não as alcançam. Sabe-se que uma criança com alguma dificuldade, porém, de escola particular, encontra-se inserida na classe "normal" mas acompanhada por um sistema de apoio que a compatibiliza com o contexto escolar.

O trabalho de HANFT \& STRIFFLER (1995) aponta uma clara tendência do modelo americano de ensino adaptar-se aos alunos e incorporá-los, mesmo quando estes apresentam algumas dificuldades. Discute, ainda, a importância da promoção de parcerias entre serviços e escolas visando a inserção da criança que apresenta alguma dificuldade no contexto escolar "normal". Esta inserção dentro do sistema nacional de educação seria a inclusão. Da mesma forma, aborda a importância da preparação dos 
profissionais da área de saúde e de educação para tal trabalho, construindo um sistema de suporte para as necessidades do aluno diferente.

Parece relevante assinalar que diferenças em alunos das escolas de educação infantil não chamam tanto atenção, pelo fato do aluno, ainda, não ter que cumprir rituais formais de passagem. Informações bastante diversas, trazidas por LEE e colaboradores (1998) mostram um programa governamental americano de educação intervencionista (compensatória) desde o nível da escola de educação infantil. Apesar do propósito integrativo do programa, o caráter do mesmo, parece ser discriminatório. Neste, as crianças não são afastadas da escola nem de suas salas de aula, contudo, este tipo de intervenção volta-se para as classes menos favorecidas, do ponto de vista econômico, e para as minorias étnico-raciais, a fim de compensar as defasagens impostas pelo sistema vigente naquele país (PATTO,1989).

Segundo LEE e colaboradores (1998), as diferenças contextuais entre salas influenciam sobremaneira o desenvolvimento cognitivo no curso do ano da educação infantil. Discutem ainda, a relevância do contexto da sala de educação infantil, atentando para a importância das crianças diferentes estarem mescladas com as outras percebidas como normais, e das possibilidades de troca, enriquecendo ambos os lados.

A experiência deste investigador, tem mostrado que uma criança diferente dentro da creche e da sala de educação infantil, costuma ter atribuida suas diferenças a um padrão familiar. Existe quase sempre por parte da família, uma desculpa para a diferença 
apontada. Há, segundo os depoimentos colhidos nos atendimentos, sempre alguém parecido na família e que espontaneamente melhorou, ou seja, passou por uma "correção natural". É quase lugar comum escutar frases como: "ele puxou o tio fulano", ou "o pai era igualzinho e vê hoje?".

Apenas alguns alunos, dependendo do "olhar do professor", são encaminhados, precocemente -antes dos problemas se fixarem- aos serviços especializados de apoio, dentre eles, ao terapeuta ocupacional. As abordagens terapêticas ou de acompanhamento, ou de intervenção, acontecem aqui em casos leves. Entre estes citamse: dispraxias, disgrafias, discalculias, alterações de coordenação viso-motora, distúrbios de atenção e da harmonia de movimentos que conduzem à atividade.

Torna-se claro a importância de observar, do ponto de vista fenomenológico, "o circuito funcional da criança". Os desajustes em faixas etárias precoces são antecedentes importantes de alterações futuras, o que sedimenta a tese de conhecê-los (MULAS e colaboradores, 1998). O problema parece ganhar força, configurar-se, tornar-se visível com o passar da idade.

Algumas diferenças são bastante perceptíveis, considerando que emergem em situações corriqueiras como brincar em parques, construir blocos, montar quebracabeças, ouvir histórias e participar em atividades com outras crianças (KRANWITZ, 1992). Da mesma forma, a título de ilustração, pode ser observada a habilidade da criança em manipular a tesoura, transitar com segurança pela escola, correr e pular. 
MULAS e colaboradores (1998) apontam como problemas mais freqüentes detectáveis na faixa etária entre quatro e seis anos de idade: os distúrbios de atenção, as dificuldades de conduta social, na direcionalidade e na compreensão de ordens mais complexas.

Em quadros como este se encaixa o trabalho do terapeuta ocupacional. A terapia ocupacional fundamenta-se, aqui, em oferecer subsídios, a partir de atividades terapêuticas, para que a criança minimize e até supere algumas de suas dificuldades. Torna-se importante destacar que o trabalho terapêutico não está estruturado nas tarefas acadêmicas, mas sim, no desempenho de tarefas que ajudem a desenvolver habilidades e corrigir padrões que impeçam a criança de participar na vida escolar conforme o esperado, segundo critérios pedagógicos. Nem todas as crianças com dificuldades precisariam ser tratadas ou encaminhadas para o serviço de terapia ocupacional. $O$ serviço se prestaria àquelas cuja defasagem, demanda escolar, versus desempenho do aluno resultasse em necessidades acadêmicas visualizadas pelos docentes (BUNDY, 1991).

Ressalta-se que, dentro do trabalho do terapeuta ocupacional, além do caráter prático da aprendizagem, deve ser considerado o quadro emocional da criança, onde estão envolvidas a auto-estima e suas emoções sendo que, em quadros como estes emergem frustrações e ansiedades diversas. Pode-se afirmar de maneira confortável, que 
o aprender está fortemente, associado com a conquista da felicidade (STEPHENSON e colaboradores, 1991).

Nos alunos onde estas diferenças são deixadas de lado, os quadros tendem a evoluir do "não aprendizado" até, a evasão escolar. Ainda com relação às diferenças encontradas nos alunos, destacam-se os problemas de adequação comportamental que se confundem com os problemas de saude. Desta forma, a demanda da Terapia Ocupacional apresenta grande variabilidade de situações problemáticas.

Pode-se afirmar que o serviço público tem uma importante participação na avaliação, intervenção, acompanhamento e resolutividade destes problemas. As equipes de saúde que contam com o terapeuta ocupacional, mesmo sem possuir um programa específico de saúde escolar, recebem um contingente significativo de crianças, tendo como mote o atraso ou o mau comportamento na escola. A prática cotidiana de duas décadas de trabalho deste pesquisador confirma tal fato.

Estes dados de realidade permitem divisar que a Terapia Ocupacional tem um papel relevante, porém não definido, delineado, conhecido e divulgado, junto aos outros profissionais da área de saúde, educação e da população. Sabe-se, entretanto, que o profissional da área dispõe de condições para sugerir e planejar, bem como, participar nos programas de acompanhamento da escola de educação infantil e fundamental, não só explicitando o problema da criança mas, fazendo "a ponte" entre casa e escola, de modo 
que "ela" possa ser vista e compreendida de forma integral, sentindo-se apoiada e subsidiada.

É significativo balizar que o trabalho na área de educação infantil é mais preventivo do que remediador (LEE e colaboradores, 1998).

Com estes aspectos em mente, considerando algumas experiências observacionais de trabalho como terapeuta ocupacional, pretende-se conhecer a capacidade diagnóstica do professor, a adequação dos encaminhamentos para os procedimentos necessários, e a familiaridade dos docentes com a Terapia Ocupacional.

Torna-se importante salientar que a palavra diagnóstico foi usada para ilustrar o contexto. É de senso comum que, muitos encaminhamentos feitos pelos professores de educação infantil, aos serviços de saúde não discorrem sobre a diferença ou a dificuldade ou o problema apresentado pelo aluno no desempenho das tarefas e na sala de aula. As solicitações de atendimento feitas pelos professores costumam vir carregadas de termos médicos/técnicos a fim de acentuar, talvez, a urgência do professor e a necessidade do aluno.

Acredita-se que a partir do discurso do professor, obter-se-á um material significativo para a compreensão de como e do que é percebido como alteração de aprendizagem ou alteração de desenvolvimento em sala de aula de educação infantil. Estes discursos poderão fornecer dados importantes sobre possibilidades de intervenção 
precoce nos problemas de saúde das crianças de escolas de educação infantil, bem como, oferecer fundamentos para a construção de um trabalho entre estas escolas e os serviços de Terapia Ocupacional. 


\section{2-OBJETIVOS}

\section{1-Objetivo geral}

Identificar as percepções predominantes na rotina de trabalho do professor com alunos de educação infantil que, sob sua ótica, apresentam diferenças.

\section{2-Objetivos específicos}

1- Conhecer as capacidades perceptivas do professor frente aos alunos de educação infantil que apresentam comportamento diferente que possam afetar o seu desempenho;

2- Identificar as condutas do professor na presença das dificuldades dos alunos de educação infantil;

3- Divisar o conhecimento do professor no que tange ao trabalho do terapeuta ocupacional;

4-Caracterizar aspectos do atual perfil contextual do professor de educação infantil da rede pública. 


\section{3-MÉTODO}

Mesclaram-se dois procedimentos técnicos. Primeiramente, identificou-se de forma aleatória, os professores e as escolas a serem investigadas; posteriormente, os professores escolhidos responderam as entrevistas que foram analisadas, de acordo com a técnica qualitativa proposta por LEFÈVRE (1998). Esta técnica está pautada na revisão dos depoimentos das pessoas entrevistadas e permite reconstruir suas representaçōes sociais sobre determinado tema (MINAYO,1996). Neste trabalho o tema principal foi conhecer a ótica e a conduta do docente, de uma rede pública, frente ao aluno de educação infantil que apresenta desenvolvimento diferente à sua ótica, e que em função deste, se destaca do grupo a que pertence.

LEFÈVRE (1998) justifica a utilização da técnica qualitativa em pesquisa, para reduzir a taxa de arbitrariedades presentes em pesquisas quantitativas empiricas sobre representações sociais, na medida em que, nestas, os pesquisados são apresentados a um assunto previamente categorizado, normalmente de forma genérica e com poucos substratos. No tocante à técnica qualitativa, o processo se dá de maneira inversa. A primeira preocupação do investigador é deixar fluir a opinião do entrevistado, de forma a não tolher suas experiências ou, no mínimo, não reduzi-las a um lugar comum. Posteriormente, de posse dos discursos dos entrevistados, busca-se identificar os pontos e conceitos mais contundentes. 


\section{1 - Delineamento geral}

Tratou-se de um estudo analítico qualitativo que teve delineamento do tipo transversal. Este estudo foi desenvolvido por meio de entrevistas, onde através do discurso do sujeito coletivo (LEVĖFRE \& LEVÈFRE, 1999), buscou-se conhecer a percepção do professor de educação infantil frente as diferenças dos alunos que pudessem interferir nos seus desempenho escolar e/ou desenvolvimento.

\section{2 - Área de estudo}

Os professores entrevistados pertencem aos quadros funcionais da rede pública, e são provenientes das escolas municipais infantis "EMI", do município de Taboão da Serra.

Taboão da Serra é um município que está situado na sub-região Sudoeste da Grande São Paulo. Limita-se ao Norte, Sul e Leste com a Capital paulista, e a Oeste faz divisa com o município de Embu. É um dos menores municípios do Estado de São Paulo, com uma área territorial de 20 quilômetros quadrados, localizado a 15 quilômetros da Capital, a partir da Praça da Sé (GONÇALVES, 1994). Dados provenientes do site www. forumsp.org.br/perfil taboão da serra.htm informam que a população deste municipio, em 2000, é de 197.460 habitantes. 
A Prefeitura Municipal de Taboão da Serra possui, sob administração direta, trinta e duas escolas de educação infantil. Todas as escolas municipais de educação infantil de Taboão da Serra atendem crianças na faixa de 4 a 6 anos de idade, em periodo parcial, sendo que a maioria delas atendem em três periodos divididos nos seguintes horários: das 7:00 às 11:00 horas, das 11:00 às 15:00 horas, e das 15:00 às 19:00 horas. Todos os professores da rede possuem como exigência mínima para exercício do cargo o diploma de magistério.

\section{3 - A amostra}

A escolha das unidades participantes, neste estudo foi feita por meio de sorteio entre as trinta e duas unidades, em reunião de diretores, com a presença do Secretário de Educação do município, e também parte da assessoria do gabinete. A escolha do município de Taboão da Serra se deu em função da disponibilidade pessoal e administrativa da Secretaria Municipal de Educação de Taboão da Serra, além do consentimento das direções dos estabelecimentos.

Foram sorteadas, de forma aleatória, 50\% (cinqüenta por cento); ou seja, dezesseis das trinta e duas escolas pertencentes ao município e presentes à reunião com o secretário. Por ocasião da visita da pesquisadora, foram sorteados dois professores de cada unidade educacional selecionada, para responder a entrevista. 


\section{4 - População de estudo}

Foram entrevistadas 32 (trinta e duas) professoras da rede pública direta de educação infantil do municipio de Taboão da Serra, obedecendo os critérios descritos. Entretanto, ao final dos trabalhos, houve a necessidade de retirar da amostragem dois professores, face às dificuldades técnicas de gravação.

\section{5 - Período de estudo}

As entrevistas foram feitas durante os meses de março e abril de 2001 pela própria autora.

\section{6 - Organização dos dados}

A análise dos discursos colhidos por questionários, a partir da entrevista direta com professores sorteados, foi realizada utilizando-se o instrumento de tabulação de dados qualitativos, proposto por LEFĖVRE e colaboradores (2000). Tal proposta implica na utilização e identificação sistemáticas das seguintes figuras metodológicas: Idéia Central, Expressões-Chave e Discurso do Sujeito Coletivo.

- Idéia Central: é uma, ou um conjunto de afirmações, que permite traduzir o essencial do conteúdo discursivo explicitado pelos sujeitos em seus depoimentos. Assim, a idéia central deve contemplar as afirmações, as negações e dúvidas a respeito da realidade factual, bem como, os juízos 
de valor a respeito da realidade institucional ou o contexto social dos sujeitos que estão envolvidos.

- Expressões-Chave: são trechos selecionados dos discursos dos sujeitos, que ilustram as idéias centrais e as ancoram.

- Discurso do Sujeito Coletivo: é a reconstrução, com base nas análises dos discursos individuais, de um discurso-sintese, que permite a expressão direta das representações sociais. Afirma-se, ainda que é a transformação do conjunto de expressões chave em um discurso-sintese, encadeado, sendo que todo material que forma o discurso encontra-se nestas expressões. Pode-se afirmar que o discurso do sujeito coletivo é o ponto de fusão dos depoimentos, com a identificação dos "pares". Pela similaridade de idéias, elabora-se o discurso de um grupo sobre tal assunto. Extrai-se, ou melhor, edifica-se o "colóquio" da representação social sobre cerla temática, é, portanto a organização das tipologias encontradas nas idéias centrais com os discursos subjacentes.

Após a coleta dos discursos individuais, estes foram organizados, tabulados e agregados para a identificação das figuras metodológicas já descritas que, "a posteriori", permitiram a emergência da fala ou discurso do social. Por razões operacionais selecionou-se três perguntas e suas respectivas respostas para análise do discurso do sujeito coletivo. Todas as entrevistas foram transcritas para permitir o procedimento analítico. O restante dos dados coletados será objeto de futuras publicações 


\section{7 - Procedimentos}

No início dos trabalhos elaborou-se um questionário (Anexo 1 ). $\mathrm{O}$ intuito deste questionário foi padronizar a abordagem dos professores conferindo à entrevista individual um eixo comum de perguntas e de ordem nas respostas, de forma que o entrevistado se colocasse em uma situação de maior conforto ao responder às perguntas chaves .

Para que o questionário fosse estruturado e alicerçado em perguntas consistentes aos objetivos do trabalho formulou-se previamente um manual de questionário para examinar a pertinência de cada questão a ser respondida pelos pesquisados (Anexo II).

Ainda com o sentido de facilitar o trânsito da autora pelas escolas e tornar mais confortável as respostas dos professores, optou-se por realizar uma primeira entrevista com os diretores das instituições. Acreditando, também, que este procedimento viria de encontro às expectativas administrativas/burocrática das mesmas. Desta forma o perfil das escolas e dos seus respectivos diretores fez parte do momento inicial das entrevistas. Elaborou-se, igualmente, o manual deste procedimento (Anexos III e IV).

Toda entrevista foi gravada, com o devido consentimento do entrevistado.(Anexo V). O equipamento de gravação utilizado para as coletas de depoimentos foi um gravador microcassette da marca Panasonic, modelo RQ-L 309. 
Como cuidado adicional, do ponto de vista ético, solicitou-se formalmente aos estabelecimentos, o acesso aos professores, bem como, foi apresentado um termo de compromisso do investigador com as informações obtidas em cada escola (Anexo Vl e VII).

Antes do início dos trabalhos de campo (março de 2001) foram aplicados cinco pré-testes, com professores aposentados e em atividade, para avaliar a qualidade investigativa e a adequação das perguntas. Inicialmente, foram aplicados 2 (dois) formulários como primeiro pré-teste, posteriormente, após novo ajuste no tocante à pertinência das respostas e expectativa de tempo de entrevista individual, os formulários foram, então, revisados e aplicados a outros 3 (três) professores distintos. Após estes dois momentos do pré-teste, o questionário apresentado em anexo, foi definido como adequado e passivel de ser utilizado no momento principal da pesquisa. Após todos estes procedimentos estabeleceu-se o formulário definitivo.

\section{8 - Aspectos éticos}

O presente trabalho foi aprovado pelo Comitê de Ética em Pesquisa da Faculdade de Saúde Pública da Universidade de São Paulo, com o número de protocolo 293 em reunião ordinária realizada em 18/04/2000, em fase anterior a pesquisa de campo. 


\section{4 - RESULTADOS}

Os resultados estão apresentados em duas partes. A primeira tem por objetivo situar o universo de professores estudados dentro de algumas características demográficas e sócio-culturais na forma de tabelas e gráficos com comentários específicos. Na segunda parte dos resultados estão apresentadas as categorias analisadas a partir dos discursos dos professores de educação infantil a respeito de seus alunos.

\section{1 - Uma foto do professor de educação infantil}

Em primeiro lugar, destaca-se que todos os professores entrevistados foram do sexo feminino.

A tabela 1 mostra que a faixa etária dos professores de educação infantil entrevistados variou de 21 (vinte e um) a 48 (quarenta e oito anos) de idade, com a média de 31,7 anos, desvio padrão 7,6 e a mediana foi 30 anos. Chama atenção a presença de professores em todas as faixas etárias estudadas.

Tabcla 1 - Númcro c porcentagcm das professoras dc cducacão infantil cntrcvistadas, scgundo faixa ctária, no Município de Taboão da Scrra, cntrc março c abril de 2001.

\begin{tabular}{c|c|c}
\hline Idade em anos & $\mathbf{N}^{\circ}$ & $\%$ \\
\hline $21-25$ & 9 & 30,0 \\
$26-30$ & 6 & 20,0 \\
$31-35$ & 7 & 23,3 \\
$36-40$ & 3 & 10,0 \\
41 ou mais & 5 & 16,7 \\
\hline TOTAL & 30 & 100,0 \\
\hline
\end{tabular}


Ao se analisar a situação conjugal das professoras entrevistadas, gráfico 1 , percebe-se que cerca de $3 / 4$ das entrevistadas são casadas e vivem com seus parceiros, e apenas $26 \%$ são solteiras.

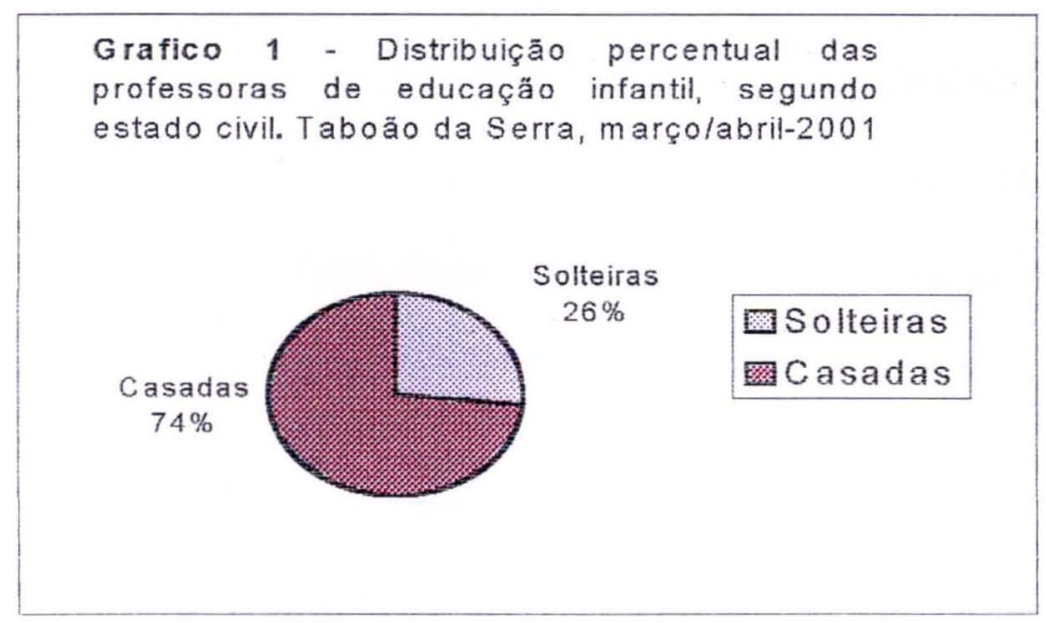

No tocante a experiência de maternidade, entre estas professoras, observou-se que aproximadamente $50 \%$ são mães. Ressalva-se que uma das professoras entrevistadas encontrava-se em estado de gestação de seu primeiro filho (Gráfico 2).

Gráfico 2 - Distribuição percentual das professoras segundo a condição de maternidade. Taboão da Serra, março/abril-2001.

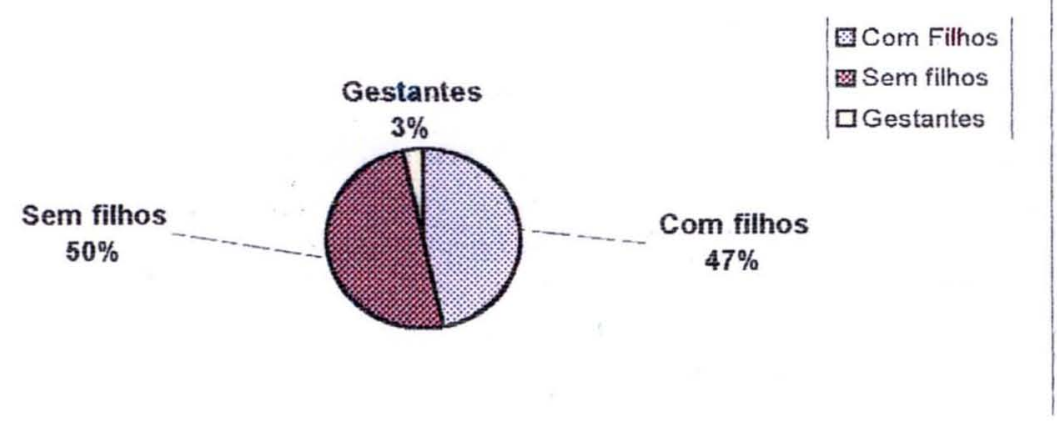


No que diz respeito à formação educacional do grupo estudado (tabela 2), oito professoras completaram o curso superior de Pedagogia (26\%). Quatro professoras de educação infantil (13\%), têm formação superior, porém não em pedagogia. Em ordem decrescente de freqüência a entrevista pessoal mostrou que duas professoras cursaram Administração de Empresas, uma Educação Artística e outra Direito. As entrevistas mostram ainda que cinco professoras estão cursando pedagogia e sete, interromperam o curso superior de pedagogia. Cabe ainda destacar que seis professoras $(20 \%)$ não têm curso superior.

Tabela 2 - Número e porcentagem de professoras de educação infantil entrevistadas, segundo a formação acadĉmica, no Município de Taboão da Scrra no pcriodo cntrc março c abril de 2.001 .

\begin{tabular}{l|c|c}
\hline \multicolumn{1}{c|}{ Formação } & $\mathbf{N}^{\mathbf{0}}$ & $\mathbf{\%}$ \\
\hline Curso superior pedagogia completo & $\mathbf{8}$ & 26,6 \\
\hline Curso superior pedagogia incompleto & 12 & 40,0 \\
\hline Outros cursos superiores & 4 & 13,4 \\
\hline Sem formação superior & 6 & 20,0 \\
\hline Total & $\mathbf{3 0}$ & $\mathbf{1 0 0 , 0}$ \\
\hline
\end{tabular}

O gráfico 3 apresenta a carga horária de trabalho dos professores. Observa-se que trinta por cento, ou seja, nove professoras de educação infantil entrevistadas trabalham apenas em um periodo (quatro horas/dia) e o restante setenta por cento ou vinte e uma professoras, trabalham periodo integral (oito horas/dia). 
Gráfico 3 - Distribuição percentual das professoras de educação infantil, em relação à carga horária de trabalho. Taboăo da Serra, março/abril-2001.

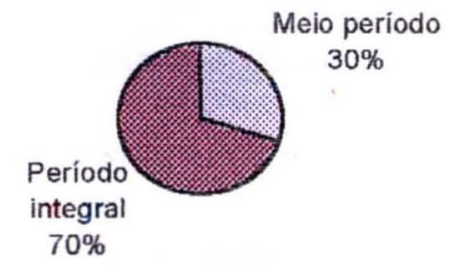

A tabela 3 mostra a grande variabilidade, no tocante ao tempo de magistério, dos professores entrevistados. Observa-se uma variação entre um e vinte e oito anos de atividade docente.

Tabcla 3 - Númcro c porcentagem de professoras de cducação infantil entrcvistadas scgundo o tempo de magistćrio, no Município de Taboão da Scrra, cntre março c abril de 2.001 .

\begin{tabular}{c|c|c}
\hline $\begin{array}{c}\text { Tempo de Magistério (em } \\
\text { anos) }\end{array}$ & $\mathbb{N}^{0}$ & $\%$ \\
$\leq 5$ & 5 & 16,7 \\
$6-10$ & 14 & 46,6 \\
$11-15$ & 8 & 26,7 \\
$16-20$ & - & - \\
$\geq 21$ & 3 & 10,0 \\
Total & 30 & $\mathbf{1 0 0 , 0}$ \\
\hline
\end{tabular}


A tabela 4 foi construída a partir da síntese das categorias escolares dos pais dos professores. Este procedimento permitiu a discriminação dos pais em três estratos segundo a escolaridade (baixa, média e superior). Pouco mais de dois terços dos pais dos professores têm pouca ou nenhuma qualificação escolar formal fazendo com que, os mesmos, participem do mercado informal de trabalho priorizando trabalhos manuais. Entre os restantes, noventa por cento dos pais dos professores (nove entre dez) cumpriram regularmente o ensino fundamental e médio. Apenas um dos pais dos professores entrevistados tem nível superior completo.

Tabela 4 - Número e percentagem dos pais das professoras entrevistadas, segundo a qualificação escolar exigida para o trabalho, no Município de Taboão da Serra Março/Abril -2001.

\begin{tabular}{l|c|c}
\hline \multicolumn{1}{c|}{ Qualificação escolar } & $\mathbf{N}^{\circ}$ & $\%$ \\
\hline Baixa ou nenhuma qualificação (trabalho manual) & 20 & 66,7 \\
Média qualificação escolar & 9 & 30,0 \\
Qualificação escolar superior & 1 & 3,3 \\
\hline TOTAL & 30 & 100,0 \\
\hline
\end{tabular}

\section{2 - Uma jornada pelo pensamento dos professores de educação infantil}

Para esta fase do trabalho foram selecionadas três questões seqüenciais, a saber:

1 - "Pra você o que é uma criança diferente?"

2 - "O que você fez diante da criança diferente?"

3 - "Para que serve a terapia ocupacional?" 
Para descrever as respostas, optou-se por apresentar um a um os discursos em sua integra. Cada uma das categorias sintetiza o conjunto das expressões-chave, identificadas em cada uma das respostas, que contemplam o pensamento do professor de educação infantil (Idéia Central). A transcrição dos discursos é apresentada por um par indicador onde a letra contempla a categoria e o número indexado à letra, o número de identificação do professor. A fim de facilitar a compreensão do trabalho, construiram-se quadros-sinteses das idéias centrais obtidas em cada uma das respostas.

\section{1"PERGUNTA -"PRA VOCÊ O QUE É UMA CRIANÇA DIFERENTE?"}

\begin{tabular}{l}
\hline \multicolumn{1}{c}{ Quadro síntese das idéias centrais } \\
\hline A - "Dificuldades de relacionamento" \\
\hline B - "Todas são diferentes" \\
\hline C - "Diferenças associadas a faixa etária" \\
\hline D - "Não acompanha" \\
\hline E - "Aparência física" \\
\hline F - "Associado a presença de deficiência" \\
\hline G - "Associado a comportamentos destoantes" \\
\hline H - "Associado ao modelo familiar"
\end{tabular}

Categoria A (Idéia Central) - "Dificuldades de relacionamento"

\section{Expressões-chave}

A. 1) Quando ela não consegue se socializar...

A.5) Você percebe dificuldade de relacionamento em sala de aula... 
A.28) Quando ela não se enturma, quando ela não se comunica com você...

\section{Discursos individuais}

A-1) Diferente das outras crianças, do contexto das outras crianças... Diferente das outras crianças. Quando ela não consegue se socializar com outras crianças, quando ela não consegue participar de nenhuma atividade proposta, depois que a professora apresenta várias atividades, usa de várias estratégias, e quando a criança tem um comportamento diferente do normal, "o que seria o comportamento diferente do normal? " quando nós pedimos prá criança sentar ela não consegue, quando pede pra ela participar... se colocar ela não consegue, ela se fecha muito mas..., não fechar de timidez, que é um fechar diferente, ela não tá presente ali, a criança está de corpo... só corpo presente.

A-5) Olha, é dificil né? Você falar assim que uma criança é diferente, mas quando você começa perceber mesmo dificuldade de relacionamento em sala de aula, quando todo mundo tá conseguindo e aquele aluno, às vezes, tá com uma dificuldade maior, às vezes, até na maneira da criança... até andar, você percebe que alguma coisa não tá legal com ela.

A-28) - Quando ela não se enturma, quando ela não se comunica com você, quando ela não se expõe eu acho, quando ela não se... deixa transparecer, não quer aparecer, se isola. 


\section{Discurso do Sujeito Coletivo}

"Você percebe que alguma coisa não tá legal com ela, você começa perceber mesmo dificuldade de relacionamento em sala de aula, ela não consegue se socializar com as outras crianças, ela não se enturma, não se comunica com você, ela não se expõe, não se deixa transparecer não quer aparecer, se isola."

Categoria B (Idéia Central) - "Todas são diferentes"

\section{Expressões-chave}

B-2) Todos nós somos diferentes, porque não existe ninguém igual a ninguém...

B-10) Todas são diferentes uma das outras...

B-12) Não sei, porque todas são diferentes...

B-14) Todo mundo é diferente de todo mundo...

B-15) Eu acho que esse olhar de diferença tem que tá na maneira de trabalhar do professor...

B-16) Porque todos são diferentes...

B-20) Eu acho que todas crianças são diferentes, todas elas...

B-23) Todas são diferentes umas das outras...

B-24) Eu acho que nenhuma é igual... 


\section{Discursos individuais}

B-2) Eu parto do pressuposto que todos nós somos diferentes, porque não existe ninguém igual a ninguém, todos nós temos nossas diferenças, nossa individualidade. É nesse sentido que você quer dizer? No meu ponto de vista, é que todos são diferentes... assim dado por exemplo: eu sinto dificuldade em alguns casos que a gente acha especial... não que... assim ele seja diferente dos demais mas, por toda uma questão de... a gente não conseguir alcançar, é igual eu tô com um aluno agora, ele não se concentra nas atividades, assim...é dificil chamar atenção.

B-10) Todas são diferentes uma das outras: Agora esses... todas essas que são diferentes uma das outras.

B-12) Ela é diferente...? Ela...! Não sei....quando ela é diferente, porque todas as crianças são diferentes... Porque elas têm em vários momentos, anseios, vontades diferentes umas das outras, elas não são iguais, não que eu as trate diferente mas elas são de natureza diferente uma das outras, é minha opinião.

B-14) Eu acho tão complicada essa coisa de dizer que é diferente, eu sou diferente de você, todo mundo é diferente de todo mundo, né, mas eu costumo pensar diferente quando fala muito diferente, muito diferente, sabe, não tem ... como que eu vou explicar isso muito diferente, tá..., não é parecido... então quando tá muito pouco parecido, daí eu acho que ela já começa a ser uma criança diferente. 
B-15) Nossa, quando é diferente... é complicado dizer que uma criança é diferente. Eu acho, que a criança ....acho que é desagradável até chamar uma criança de diferente, eu acho que esse olhar de diferença tem que tá na maneira de trabalhar do professor, acho que o professor deve perceber quando tem alguma coisa, que você precisa trabalhar diferente, do que você trabalha com as outras, né, agora dizer que uma criança é diferente, eu dificilmente faria isso, não faço, acho... logo a gente vê criança diferente, aqui nós temos crianças do "Casarão" né, que a gente fala são crianças portadores do HIV, né, temos crianças da "Casa de Apoio" com câncer, então esse não é nenhum motivo de chamar uma criança de diferente né, e aqui na escola nós não temos..., são todos iguais, nós temos cuidados diferentes, né.

B-17) Quando ela é diferente?! Ai é complicado porque todos são diferentes, cada um tem o seu jeito, complicado de responder isso hein....não dá prá falar o que o... igual prá te falar o que é o diferente, não sei te responder essa.

B-20) Eu acho que todas crianças são diferentes, todas elas.

B-23) Diferente?! Todas são diferentes umas das outras. Cada criança tem a sua personalidade, tem o seu jeito de ser, né, tem a bagagem que ela traz de casa, então cada um é cada um, eu vejo cada criança... eu não vejo a minha classe como uma coisa única, né, nos treinamentos a gente tem muito disso de reparar as diferenças, então toda criança tem a suas diferenças, né, então eu não posso generalizar a classe, né, então vejo cada criança como uma criança. 
B-24) Diferente...olha a criança, eu acho que é assim nenhuma é igual, né, você tem que respeitar a individualidade de cada criança, mas eu acho que uma criança... é aquela criança assim: que vem mesmo falando muitos palavrões, maus costumes de casa, sabe, que você tenta mudar e a criança não muda; aquela criança que não consegue parar, também. Eu tenho um aluno, que ele é assim ele não consegue parar quieto um minuto, você tá tentando colocar ele atento a uma história, ele não consegue parar prá prestar atenção a uma história, uma brincadeira, ele não consegue ter regras, normas, ele não consegue participar daquelas regras, normas... ele é uma criança ativa, ativa não pára um minuto, prá mim é uma criança totalmente diferente da sala, que chega a incomodar as outras crianças da sala.

\section{Discurso do Sujeito Coletivo}

"Eu parlo do pressuposto que todos nós somos diferentes, porque ninguém é igual a ninguém, todos nós temos nossas diferenças, e todas crianças são diferentes umas das outras; elas tem em vários momentos, anseios, vontades diferentes umas das outras, cada um tem seu jeito, cada criança tem a sua personalidade; eu costumo pensar diferente quando fala muito diferente, nos treinamentos a gente tem muito disso de reparar as diferenças. Acho que esse olhar de diferença tem que tá na maneira de trabalhar do professor, eu não vejo minha classe como uma coisa única, 
nenhuma criança é igual, você lem que respeilar a individualidade de cada criança."

Categoria C -(Idéia Central) - "Diferenças relacionadas a faixa etária"

\section{Expressões-chave}

C-4) Não estão de acordo com as características que as crianças da mesma idade demonstram.

C-13) Quando não é igual as outras...

C-21) Quando aquele aluno foge da regra geral.

C-30) Quando eu comparo ela com as demais crianças, quando ela não acompanha o comportamento habitual daquela idade....

\section{Discursos individuais:}

C-4) Como assim é diferente? Bom, vindo de outra pessoa dizer que ela é diferente eu entendo que ela tem problemas específicos, que não estão de acordo com as características que as crianças da mesma idade demonstram. A gente vê que a criança se isola, ela tem isolamento, ela tem dificuldade com relacionamento, aí a gente percebe que há um problema dela né? Algum problema escondido que ela, talvez familiar, algum problema fora da escola.

C-13) Diferente ??? Humm... quando não é igual as outras. Eu tive no ano passado uma criança, que prá mim ela era diferente. Porque é criança do pré, nunca tinha ido prá escola, quando $90 \%$ das crianças não tinham problemas, mas ela era uma criança dificil 
assim, não se interava com ninguém, por mais que a gente... a sala toda se voltasse prá ela, ela não se interava nas musicas, nas brincadeiras e nem... ela tinha uma prima que estudava na mesma classe, nem com a prima. Então eu fui perguntar prá mãe, como que ela era em casa, e a mãe dela falou que nem com a família ela conversava, que ela era uma criança dificil de se comunicar que ela percebia, quando por exemplo... quando a criança queria ir ao banheiro porque, ela ficava segurando, mas ela não se comunicava. Isso prá mim é uma criança diferente.

C-21) Em que sentido assim, de comportamento? Eu tenho a sala eu avalio aluno por aluno, quando aquele aluno foge da regra geral.

C-30) É diferente quando eu comparo ela com as demais crianças, quando ela não acompanha o comportamento habitual daquela idade, ela tem um comportamento diferente, então aí eu tenho que buscar porque ela tem aquele comportamento diferente, tenho que fazer uma investigação, né, prá saber se é algo natural, ou se é um problema de saúde alguma coisa assim.

\section{Discurso do Sujeito Coletivo}

"Quando não é igual às outras. Eu entendo que ela tem problemas especificos que não estão de acordo com as características que as crianças da mesma idade demonstram. Eu tenho a sala, eu avalio aluno por aluno e quando aquele aluno foge da regra geral e tem "aquele" comportamento, 
lenho que fazer uma investigação prá saber se é algo natural ou se é um problema de saúde."

\section{Categoria D (Idéia Central) - "Não acompanha"}

\section{Expressões-chave}

D-3) Que não acompanha as outras...

D-18) Ela não acompanhava a sala...

D-19) Quando não tem atenção...

\section{Discursos individuais}

D-3) Não sei...que não acompanha as outras, seria?

D-18) Olha eu acho que ...eu não sei, assim, pela experiência que eu tenho de tantos anos, eu não sei se posso dizer uma criança é diferente, não é, e cada um tem seu jeitinho seus limites, e a gente vai adaptando o trabalho de acordo com a criança, mas não sei, assim, criança diferente, e tive criança com problema mesmo, era até pra ir pro "Amor Perfeito" né, ela não acompanhava a sala, e fazia tratamento com neuro, com fono ela era totalmente....ela não se prendia a atividades não, e era dificil o trabalho, mas ela ..não sei se isso seria uma criança diferente, possa ser né, talvez... talvez fosse, porque pelo tipo de comportamento na sala de aula, gritava, se batia, às vezes tinha ataque epiléptico, então era bem complicadinho, talvez essa, porque ela necessitava de maiores cuidados meus, né, talvez isso. 
D-19) Quando ela não tem atenção, que eu percebo que tá alguma coisa diferente, né, quando ela não tem atenção e quando ela não consegue se concentrar no que eu tô...dando ela não demonstra nenhum interesse sobre aquilo, então eu começo a observar qual é a dificuldade que ela tem.

\section{Discurso do Sujeito Coletivo}

"Seria aquela que não acompanha as outras, não acompanha a sala, que não se prende às atividades, não consegue se concentrar, quando não tem atenção."

Categoria E (Idéia Central) - "Aparência física"

\section{Expressões-chave}

E-6) Apresenta alguma deficiência de linguagem, alguma deficiência física...

E-9) Aparência dela...

E-11) Algum problema de retardo mental ou deficiência física...

E-25) A gente olha o fisico se tá perfeito...

\section{Discursos individuais}

E-6) Diferente em que sentido? Fisicamente, mentalmente ou em todos os sentidos? Quando ela apresenta alguma deficiência de linguagem, alguma deficiência física, ai ela se torna diferente. 
E-9) Tem que falar uma coisa só? Ahn! Se eu não conheço a criança e eu já vejo, né; a aparência dela, o comportamento dela e ai depois conhecendo né, se ela é agitada, agressiva, tinhosa ou não, sabe, acho que tudo isso...bom. E depois quando não se concentra no que eu estou falando, seja ela, lição ou alguma coisa muito mais gostosa, né, música, história, é uma criança diferente; mas tendo isso eu gosto de trabalhar com criança assim, eu tento sabe, ir descobrindo aos poucos o que falta pra ela. Eu tenho um aluno assim aqui, a primeira vez ele chegou, ele tinha os cabelos ruivos né, eu já perguntei: - Nossa seu cabelo é ruivo! como, como você é diferente, olha faltava uma pessoa assim aqui né. Ai ele falou que ele pintou o cabelo, tingiu o cabelo. E agora ele tá careca né. E ele não consegue, não conseguia acompanhar nada na escola, fazia bolinhas sabe, sem noção de limpeza nenhuma, e não respeitava a mãe em casa, e aí eu descobri que ele é filho de um presidiário. E hoje em dia, ontem aliás, eu fui falar com a mãe dele: Como ele está em casa? E ela disse assim que ele tá tão diferente e respeitando ela, então ela sentiu me agradeceu bastante, quanto a isso. E ele não me dá trabalho aqui, sabe assim de, de comportamento, me dá, eu tenho que pegar no colo, pegar, pegar na mão dele, né, fazer pontilhados porque ele não tinha noção alguma e hoje em dia ele tá bem melhor.

E-11) Eu.. quando uma criança é diferente prá mim, é quando uma criança tem algum problema de retardo mental, ou deficiência física, e assim retardo mental que seja grave, porque leve a gente...né...eu acho que a criança supera numa boa, a gente também consegue superar numa boa, não retardo....porque eu trabalhei também no "Amor 
Perfeito" no ano passado. Então quando aqueles graves que dá pra perceber bastante que a criança é diferente tanto na reação dela, os cuidados com ela é diferente, né, porque tem muitas crianças em cadeiras de rodas e tudo, é uma criança diferente realmente, se bem que nós temos muitas crianças lá no "Amor Perfeito", que são bem espertas, se você olhar, você acha que não tem nada a ver... você conhecendo, cê trabalhando dos dois lados, que no Estado eu trabalhei também muitos anos com classe, essas classes especiais, então a gente sempre trabalhando com criança com deficiência, e mesmo com classe normal, com criança deficiente assim, deficiência leve né, e eu fiz curso na USP, também DM, e são tudo coisa que dá pra superar numa boa, e que a criança não consegue atingir aquele objetivo que a gente .. que os outros atingiram, não é nem que a gente gostaria, e que outros atingiram mas é questão de tempo, né, às vezes um ano, 2 anos, às vezes consegue depende da gravidade do caso dela, mas pra mim diferente só se for uma coisa que dá muito pra perceber, uma lesão grave ou deficiência física que a gente percebe que ela é diferente, não assim intelectualmente, fisicamente, precisa ver o que você quer ver, qual a diferença que você quer né.

E-25).Quando uma criança é diferente...? Bom, primeiro a gente olha o físico, se tá perfeito, se anda, se tem todos os dedos, se tem braço, se não tem, depois tem casos de crianças que não tem concentração, às vezes, tem problema de visão, problemas de fala na linguagem da criança, é só observando, mas no primeiro momento a gente olha o fisico. 


\section{Discurso do Sujeito Coletivo}

"Quando ela apresenta alguma deficiência de linguagem, alguma deficiência fisica. Se eu não conheço a criança eu vejo a aparência dela, quando tem algum problema de retardo mental ou deficiência fisica porque tem muitas crianças em cadeiras de rodas, é uma criança diferente, realmente uma coisa que dá prá perceber, uma lesâo grave ou deficiência que a gente percebe. A gente olha se o fisico está perfeito, se anda, se tem todos os dedos, se tem braços, às vezes tem problema de visão, de fala, na linguagem da criança, mas primeiro a gente olha of fisico."

Categoria F (Idéia Central) - "Associado a presença de deficiência" Expressão-chave

F-29) Quando ela é portadora de alguma necessidade especial...

Discurso individual

F-29) Diferente?!?... Quando ela é portadora de alguma necessidade especial.

\section{Discurso do Sujeito Coletivo}

"Quando ela é portadora de alguma necessidade especial". 
Categoria G (Idéia Central) - "Associados a comportamentos destoantes"

\section{Expressões-chave}

G-7) Tem atitudes assim, digamos, bem diferenciadas das atitudes...

G-8) Apresenta um comportamento diferente dos outros, né, ou agressivo ou um emocional diferente...

G-16) Dependendo do comportamento que ela tem na parte de agressividade, ela se torna uma criança diferente...

G-27) Certas dificuldades, né que elas apresentam...

\section{Discursos individuais}

G-7) Você diz diferente em ações, atitudes? Olha, eu dou um exemplo claro de um aluno que eu tenho esse ano, prá ficar mais fácil: primeiro dia que esse menino chegou prá mim eu olhei prá ele e falei: ele é diferente de todos os meus alunos desta sala, e continua sendo ele tem atitudes assim, digamos bem diferenciadas das atitudes dos meus trinta e alguns que eu tenho, eu tenho 33 ele é bem diferenciado. Se o primeiro dia esse menino ele... se jogava no chão, ele batia a cabeça no chão, ele chorava, ele menino, ele se agredia, ao mesmo tempo ninguém podia chegar perto dele, nós tivemos que trancar a porta prá segurar o menino dentro da sala, ele se debatia no chão, chorou, chorou nos primeiros dias chorou, depois foi modificando as atitude, mas ele continua sendo, digamos assim, vamos usar a palavra destaque, prá mim porque ele é assim ele fala sozinho, ele usa um linguajar que eu não consigo entender, parece que ele se retrai fica falando prá si mesmo o tempo inteiro, ele é agressivo, ele é assim: ele tá sentado, de 
repente ele levanta e bate em um, ai senta de novo, ai levanta bate em outro e senta de novo; vamos fechar assim eu acho atitudes, determinados comportamentos é que fazem eu achar uma determinada criança é diferente uma da outra. Eu tô citando caso desse, mas eu já tive vários outros, por apatia, crianças que não falam prá fazer xixi, fazem gestos, principalmente nesta faixa etária. Eu tive uma aluna no pré que ela não falava, ela só vinha com a mãozinha eu já percebia que ela queria fazer xixi. Mas ela não abria a boca, então são comportamentos que eu acabo achando que a criança é diferente. Quando a gente fala diferente, todo mundo já pensa ou tem alguma deficiência ou é indisciplinado, não, eu acho que tem diferenças diferenciadas, vamos dizer assim. Eu tenho um caso deste menino aqui que realmente eu mandei chamar a mãe, nós conversamos, eu cheguei, nós colocamos até um sério problema de excesso televisivo, assiste televisão o tempo inteiro e só desenhos agressivos. Então de primeiro instante, quando a mãe já me contou este caso, eu falei ele tem um reflexo do que ele vê na televisão; como ele é filho único, quando ele chega aqui ele quer passar o que ele vê na televisão pros amigos. Mas é assim, ele tem uns surtos, ele tá ...daqui a pouco ele grita, dá assim a impressão dele ter o mundo dele, ele não percebe que ele está em uma sala de aula com 30 crianças a sua volta. Ele progrediu muito mas, ele continua ainda com alguns surtos, de vez em quando na sala de aula. E tem assim outras crianças que não tinham o caso dessa, mas não abriam a boca prá nada, eu passei 1 ano com essa menina na educação infantil, eu consegui alfabetizar essa menina, sem ouvir ela quase falar. Eu descobri que ela estava alfabetizada porque ela caiu justamente na sala de $1^{\text {a }}$ série da minha amiga, olha a sua menina está alfabetizada. Prá você ver a fase do pré pro primeiro ano, ela chegou lendo, só que no pré ela não lia, e assim se eu pedisse prá ela 
ler ela tinha um problema tão grande psicológico que dava vontade de fazer xixi e chorava, sabe se retraia, ela não ia prá passeio nenhum, hora do parque ela sentada o tempo inteiro, no meu lado, então ela se alfabetizou sozinha, assim porque sem claro ...ela fazia tudo direitinho, ela me mostrava mas não lia. No ano seguinte a minha amiga diz a Maria Inês está alfabetizada, a passagem do prẻ para a $1^{\text {a }}$ série. E assim durante o ano eu vi o caderno dela, muito caprichado, ela copiava porque copiar é muito mais fácil que ler, mas eu não tive o prazer de vê-la lendo, e ela chegou na primeira série lendo. Então eu vejo que são formas diferenciadas, são casos e casos. E assim eu procuro, principalmente, quando eu pego sala de EMI, é já selecionar assim, a gente faz uma ficha de entrevista, eu prefiro conversar com os pais. Então selecionei aqui alguns casos, chamei os pais e refiz a ficha prá ficar buscando, sabe muitas coisas... porque eu acho que não adianta ficar julgando, julgando o aluno, tentando achar uma explicação do nada, eu quero conhecer mais um pouquinho, prá saber se a gente pode tentar ver alguma coisa. Prá mim acho que de diferente no aluno é isso.

G-8) Quando ela apresenta um comportamento diferente dos outros né, ou agressivo ou um emocional diferente. Uma aluna que está chorando na classe, tem uns 3 ou 4 dias, a menina está com um comportamento diferente, alguma coisa está acontecendo por trás, que eu não estou sabendo te dizer o quê, mas está acontecendo.

G-16) Quando é diferente ?! Ah! Eu acho que pra mim ela é diferente, dependendo do comportamento que ela tem, na parte da agressividade, ela se torna uma criança diferente, porque todas as crianças não são iguais né, cada um se diferencia pelo... não é 
comportamento.....pelo meio em que ela vive, né, mas também eu acho que a criança se torna muito diferente conforme a reação que ela tem, ai você vê como ela é, porque de trás de uma reação de uma criança tem toda uma história de vida.

G-27) Quando que uma criança é diferente, ah tem tantos motivos, eu acho assim... Quando, em que sentido você diz...? Você me pegou, viu, eu acho assim se você olha sem você bater um papo com a criança, sem você ter uma...é dificil, num consigo distinguir assim não. Só você conversando com essa criança, vendo diferença de cada uma tudo, você já vai notando... Certas dificuldades, né, que elas apresentam. Fala, e às vezes até pra andar a gente percebe, algumas diferenças, a verdade também tem isso, a gente percebe mais mesmo na...ué é mais na fala mesmo acho que a gente sente nessa idade.

\section{Discurso do Sujeito Coletivo}

"Ela tem atitudes bem diferenciadas, ela é bem diferenciada; são determinados comportamentos que fazem eu achar uma criança diferente da outra, são formas diferenciadas, são casos e casos: ou agressivo ou um emocional diferente, dependendo do comportamento que ela tem na parte de agressividade, ela se torna uma criança diferente, conforme a reação que ela tem, são certas dificuldades que elas apresentam". 


\section{Categoria H (Idéia Central) - "Associado ao modelo familiar"}

\section{Expressões-chave}

H-22) ...Ela tem família diferente, que tem costume diferente...

$\mathrm{H}-26)$...Eu vejo que o problema, às vezes, tá na família, ou a própria família me passa alguma dificuldade...

\section{Discursos individuais}

H-22) A criança não é diferente, ela tem familia diferente que tem costume diferente, o ser humano é diferente, você é diferente de mim com certeza, não tem aquele papo ela é quieta ela é calada, ela é muito bagunceira não existe isso, professora é que tem que se adaptar no começo, né, porque eles, eles tem menos entendimento, talvez eles entendam mais que a gente, só que eles não são diferentes, eles são iguais, só que foram criados em famílias diferentes.

H-26) Diferente ?! Você diz em nível de aprendizagem, ou quando ela se mostra diferente em sala, alguma dificuldade, assim? Olha, eu não costumo assim, que a gente diria rotular uma criança logo, na primeira impressão, o que eu tenho como conduta desde que eu entrei aqui é assim ; eu tá conhecendo essa criança eu observo se eu vejo que a criança é um pouco mais quieta ou mais do normal eu procuro, conhecer também a realidade da familia, né, porque ai eu vou procurar recursos, né, se eu vejo que o problema, às vezes, tá na família, ou a própria familia me passa alguma dificuldade com a criança eu procuro recursos, mais é depois de uma investigação mais a fundo. 


\section{Discurso do Sujeito Coletivo}

"A criança não é diferente, ela tem familia diferente que tem costume diferente. Elas são iguais, mas foram criadas em familias diferentes; eu procuro conhecer a realidade da família, eu vejo que o problema, às vezes, lá na familia ou a própria familia me passa alguma dificuldade com a criança."

\section{2" PERGUNTA- "O QUE VOCÊ FeZ QUANDO ESTAVA diANTE}

\section{DA CRIANÇA DIFERENTE?"}

\section{Quadro síntese das idéias centrais}
A -"Socorro familiar
B -"Socorro institucional"
C -"Veio indicada"
D -"Não enfrentou o problema"
E -"Professor tenta resolver o problema"

Categoria A (Idéia Central)- "Socorro familiar"

Expressões - chave

A-6) Eu chamei a mãe. 
A-14) Se eu achar mesmo que a criança é diferente, e a mãe corresponder a isso, então eu busco tá sempre conversando com a mãe.

A-15) A gente tem um contato mesmo, direto com a pessoa responsável pela criança.

A-16) Eu converso com a mãe dele.

A-22) Eu tentei falar com a família.

A-28) Primeiro eu tento chamar a família.

A-29) Primeiro quando a criança chega, acredito que você tem que tá conversando com a familia.

\section{Discursos individuais}

A-6) Primeiro conversei, porque era o primeiro dia da criança, conversando com o grupo de crianças, que a gente possivelmente tinha uma criança diferente na sala, uma criança especial que a gente ia ter que tá trabalhando com essa criancinha, de modo que se integrasse no grupo deles. Aí no dia seguinte foi que eu chamei a mãe e perguntei se ela sabia que a criança dela ser especial, e ela falou que sabia. Perguntei porque não falou, não contou prá gente, ela não quis contar : "porque eu pensei que ela não ia aceitar". Daí a gente conversou com ela, a direção teve um contato maior com ela, dai isso foi em 91 que eu trabalhei com essa criança, daí a única criança, e foi bem até o trabalho. Depois a criança participou da Apae e tudo e também foi encaminhada pela escola. A gente encaminhou. 
A-14) Não, geralmente eu pergunto como é que é, sempre mando uma pesquisa pra casa, pra todas as crianças, não só pra quem eu acho que seja diferente, pra mãe responder o que ela tá sentido da criança, nesse período na escola porquê, se tem alguma dificuldade em casa, na família ou na escola, se tem alguma sugestão ou reclamação e a gente aproveita aí pra ver se a mãe está dando indicios..., a indicação que essa criança seja mesmo diferente ou que ela precise de um... de um atendimento em especial. Aqui na escola também tem a ficha diagnóstica; quando as mães colocam a criança aqui, desde que nasceu, como foi o parto, a gestação; mais ou menos rapidinho assim, como é a criança, então a gente vai lá, resgata também tudo isso, e ai depois se eu achar mesmo que a criança é diferente, e a mãe corresponder a isso, então eu busco tá sempre conversando com a mãe.- Mas é difícil viu, às vezes é muito dificil lidar com o aluno, você não sabe o que fazer, com essa diferença. Diferente é até meio constrangedor de falar, mas você fica insegura, completamente insegura, você não sabe o que fazer, né.

A-15) Nós fazemos, mesmo no começo antes de começarem as aulas, a gente faz uma ficha diagnóstica, então a gente tem um contato mesmo, direto com a pessoa responsável pela criança né, e a gente tira uma porção de dúvidas, acaba conhecendo um pouquinho a criança né, o perfil da criança naquela ficha, já facilita bastante; agora com o fato trabalho da gente na sala, às vezes, a gente acaba... um certo carinho né, especial né, por aquela criança, mas a gente procura não deixar aparecer pros outros, não sei se conseguimos essa perfeição. 
A-16) Eu converso com a mãe dele, pra mãe dele conversar com ele em casa né, porque como base é família, né.

A-22) Olha, eu tentei falar com a familia, só que eles não aceitam nenhum tipo de opção né, você não pode opinar em nada, eu fui conversar com os pais, eu cheguei sentei, falei mãe está acontecendo..."não está acontecendo isso impossível"; eu quero saber o que acontece, eu já li todo o currículo dele mas deve ter alguma coisa a mais, e ela me falou o seguinte: "-olha, a nossa vida particular, só diz respeito a nós", o que está no currículo dele é o que a gente pode falar é o que vocês devem saber, a educação que eu dei pro meu filho só cabe a mim: E eu não posso tratá-lo diferente eu não posso ficar é com muito chamego com ele, dando mais atenção pra ele do que com as outras crianças, porque embora...ele não é diferente como as outras crianças... tem pais diferentes, e todas elas se adaptaram se eu ficar eh...dando atenção extra pra ele, ele vai continuar sendo o menininho da classe, sabe isso não pode acontecer, ele...ele tem que se adequar também e ele tem que ver porque ele tem um pouquinho de inteligência e saber que eu, também, tenho que me adequar a ele, tem coisas que eu tenho que ceder e ele também tem que ceder, uma hora ele vai ir ao banheiro, porque ele não vai ao banheiro, ele faz xixi na roupa, uma hora vai cair a ficha e ele vai ao banheiro, eu não posso bater, eu não posso obrigar, eu só falo: "vamos todos ao banheiro" todos vão ao banheiro, ele não vai ao banheiro, eu pego na mão dele ele empaca, sabe que você não pode fazer isso né , então eu deixo. 
A-28) Primeiro eu tento chamar a família...quando eu percebo que é uma coisa agravante como o ano passado que eu vi que era um problema mental, era um problema psicológico da criança, então eu chamei a família, mas eu vi que na família não teve resultado, porque a mãe achou melhor ela se excluir do problema, e achou que o filho dela era normal; então o que eu tive que fazer, eu trabalho com ele mesmo, eu e ele e os outros na sala, tanto que quando tinha um problema tinha que resolver na sala, então já ninguém ria dele... não gente não vai rir, porque isso pode acontecer: fazia xixi na roupa, peraí ninguém fez xixi na roupa? Eram coisas que se tornavam normais, ele não se constrangia e com isso ele foi aprendendo as crianças tirassem sarro, isolassem ele eu não teria conseguido o resultado que eu consegui, ele comer com colher no final do ano, que ele não comia, ele pedir pra ir no banheiro, ele pedia do jeito dele: "fessora xixi, xixi"; vai corre, corre vai ao banheiro, então era uma coisa que ele não fazia, ele já arrancava e fazia aonde ele estava, então isso eu acho que é importante, não adianta tanto a mãe vir porque a mãe, às vezes.....eu, eu sou muito contra chamar a mãe, por causa de disciplina, só chamo em casos extremos porque eu acho que eu dentro da sala, ali nas minhas quatro paredes, eu tenho que resolver o problema com ele, não adianta muito a mãe falar em casa, chega na escola continua a mesma coisa, eu tenho que ganhar a confiança dele, ele tem que confiar e gostar de mim, pra ele me respeitar e a gente pode se entender na sala.

A-29) Bom, primeiro quando a criança chega, acredito que você tem que tá conversando com a familia, tem que saber o que a criança apresenta em casa né, e se existe alguma necessidade especial, qual essa necessidade, porque se você for primeiro na diretora 
você não vai saber, a mãe que tem todas essas informações, depois dessas informações, aí eu vou me reunir com a diretora e com coordenador e até professores pra ver como que eu posso tá trabalhando, porque você sozinha né, tirar assim: Ahh! o que quê eu vou trabalhar, você de repente se depara com algo novo né, então você precisa de uma ajuda, eu acho assim que em grupo você consegue muita coisa né, uma troca de experiências assim fantástica.

\section{Discurso do Sujeito Coletivo}

"Primeiro quando a criança chega, acredito que você tem que estar conversando com a família, porque é a base. Eu tento chamar a família, se lem alguma dificuldade, se tem alguma sugestão ou reclamação, você não pode opinar; converso com a mãe dela, para ver se a mãe está dando indicação que essa criança seja mesmo diferente ou se ela precisa de um alendimento especial, a gente tem uma porção de dúvidas e acaba conhecendo um pouquinho da criança. A gente tem um contato direto com a pessoa responsável pela criança."

Categoria B (Idéia Central) - "Socorro institucional"

\section{Expressões-chave}

B-4) Eu conversei com a minha diretora.

B-5) Passei para a coordenadora. 
B-7) No caso eu passo prá direção.

B-19) Primeiro eu conversei com a escola pra tá sabendo todas as informações que eu tinha daquela criança.

B-20) A gente conversa bastante com os outros professores, inclusive com a diretora também a gente tá sempre passando alguns problemas.

B-23) Sempre, a gente costuma abrir pro grupo, né, porque geralmente o grupo tem experiência.

B-24) Então eu procuro conversar primeiro, com a direção da escola.

B-26) Eu trago sempre a questão pra R., eu acho que assim de imediato, é minha chefe e a diretora.

B-27) Eu passo pra, né, o meu superior.

B-30) A gente tem que falar com o superior

\section{Discursos individuais}

B-4) Bom, a gente sempre encontra né? É porque como a gente trabalha com muitas salas, muito numerosas, sempre encontra uma criança diferente da outra. Este ano mesmo né, há dois meses eu percebi que tinha uma criança diferente das outras, ela falava de assuntos que não estavam de acordo com a idade dela tá? Ela tinha dificuldades de relacionamento e as próprias crianças da sala já começavam a se afastar dela, né? Então eu conversei com a minha diretora; falei prá ela: olha, essa criança tem alguma coisa, talvez seja em casa tudo; aí a diretora foi e conversou com a mãe, realmente a gente percebeu que era um problema em casa; aí o que a gente tá 
trabalhando com essa criança, é tá conversando com ela, é socializando ela, ensinando para ela que certas coisas a gente não deve dizer tá, em certos momentos, que há as horas certas para falar as coisas e já melhorou bastante. Isso.

B-5) O primeiro momento eu vi se era mesmo, né, porque às vezes pode ter acontecido alguma coisa em casa e tal, mas eu não vi, e passei para a coordenadora, então a coordenadora falou que realmente aquela criança tinha muito problema de aprendizado, né, e dai foi chamada a mãe para conversar, se ela já havia procurado algum especialista né, daí a mãe falou que não. Então a partir daí ela procurou o posto de saúde próximo né, da casa dela, e foi... e conseguiu para passar encaminhamento com a psicóloga para a criança.

B-7) A primeira coisa que eu procuro fazer é me integrar com a família. Não... Resolvese na escola, no caso eu passo prá direção, que é meu superior. No primeiro dia eu já chamei a Luiza que era a diretora anterior, falei: olha Luíza, preciso conversar com a mãe desse menino, já marcamos na semana seguinte a mãe veio e aí... porque é assim, sabendo o que realmente acontece com a criança, fica mais fácil de eu tentar entender o que está acontecendo com ela em sala de aula também. No caso desse menino a televisão é o grande vício dele e assim ele traz reflexos do que ele vê na televisão prá dentro da sala de aula. Não que eu vá consertar o problema dele, mas pelo menos eu tô conhecendo um pouquinho prá saber porque ele tem determinadas atitudes. Sabe ele tem uns surtos, ele tá quietinho, de repente dá uns gritos, e algumas palavras que eu não entendo, porque eu não assisto este tipo de desenho, não sei o que fala, não sei o que 
acontece, eu deduzo que sejam palavras que ele deve ouvir lá nos desenhos que ele assiste na televisão, que são palavras totalmente desconhecidas do meu vocabulário.

B-19) Então, eu vou contar a minha experiência nesse caso; primeiro eu conversei com a escola pra tá sabendo todas as informações que eu tinha daquela criança, porque eu acho que eu tinha que tá sabendo tudo primeiro, pra poder depois tá fazendo alguma coisa com ele, aí depois de alguns meses e...avaliei a criança, conheci, aí foi marcado uma entrevista com os pais, ai nisso perguntei porque que ele...o que ele tinha... realmente até hoje, não sei se... até agora eles sabem; mas até o momento eles não sabiam, porque foi alguma coisa do nascimento, não sabiam se era genético, não tinham certeza de nada ainda, o menino vivia em tratamento e sempre que possível a fono ia na escola pra tá conversando comigo, então eu contava pra ela o que eu fazia, e ela contava pra mim o que ela fazia e sempre ela me passava exercícios, né, do que ele...pra eu poder tentar estimular a fala dele, mas ele não... até sair da escola ele não falava mesmo, ele só emitia sons, né, então o processo foi esse, a gente tá conversando com os pais, sempre eu conversava com a mãe dele, sempre tava conversando com a fono e sempre na direção, a gente tava conversando pra tá trocando idéias, elas me ajudavam porque às vezes você tá na sala, você acaba ficando cansada porque não é fácil, você tem crianças normais, né, e tem uma criança diferente, então elas sempre estavam me ajudando, sabe sempre conversando trocando idéias, que às vezes você não consegue.. sabe, você vai até certo ponto depois você não consegue, porque tá cansada, por aquela criança de você ter que...você fica emocionalmente também eh... como eu posso falar, você fica abalada também, porque você num....você quer ajudar aquela criança e ela não consegue evoluir, 
né, então elas estavam...a direção sempre estava me ajudando conversando comigo a respeito disso, era uma troca entre todos.

B-20) Geralmente a gente conversa bastante com os outros professores, inclusive com a diretora também a gente tá sempre passando alguns problemas dentro da sala, a gente tá sempre comunicando a diretora e sempre discutindo com os colegas até, às vezes, no HTC também quando a gente reúne né, as professoras da manhã e as professoras da tarde sempre a gente discute alguma coisa: olha o que quê você trabalhou, eu trabalhei assim, assim e deu certo, ou assim não deu sabe, sempre trocando né, trocando experiências. E assim a familia também, a gente tá sempre trabalhando com a família por exemplo: na primeira reunião de pais essa questão de...da criança mais levada, contei pras mães, pros pais como foi o primeiro dia de aula, contei como que eu estou trabalhando, como é o meu trabalho, sabe, então eu estaria precisando muito da ajuda delas também em casa, porque eu iniciei um trabalho aqui, mas que esse trabalho deveria ter uma continuidade em casa, né, porque não adianta a gente estar trabalhando aqui e em casa não dar essa continuidade.

B-23) Sempre, a gente costuma abrir pro grupo, né, porque geralmente o grupo tem experiência né, a gente conversa né, se não resolve a gente chama a mãe, como é em casa pergunta né, o que ele tá achando da escola, porque eu tenho o seguinte ponto de vista; a escola é o lugar da criança, aqui a criança tem que se sentir feliz, é obrigação e assim ponto de partida, ela não tá feliz vamos ver o que tá acontecendo né, então ela tem que estar, se ela tá feliz ela vai estar junto com o grupo, isso eu tenho também muito de 
grupo, a criança tem que se sentir bem no grupo que ela está, se ela não está se sentindo bem alguma coisa tem que ter, vamos chamar a mãe, vamos explicar o trabalho, se a mãe não está satisfeita com a escola a criança também não vai estar, então é assim, buscando a mãe pra ver o que está acontecendo, geralmente resolve o problema.

B-24) Eu acho que assim: quando a criança tem problema assim você não deve sair falando prá todo mundo na escola, você está rotulando a criança e de repente essa criança vá pra outra sala..., a não ser que seja um problema que você precise de um auxilio, até conversar entre os professores mas assim, falar ou discutir com servente não é desmerecendo eu acho que não é bom; não é o papel deles também, e acaba às vezes comentando fazendo um comentário na frente da criança, que eu acho que vai discriminar a criança; então eu procuro conversar primeiro, com a direção da escola, agora se ela achar que tem que ser colocado num grupo de estudo, no horário de trabalho coletivo sobre aquela criança, a gente pode até discutir sobre a criança, como cada professor coloca o seu aluno mas, eu procuro colocar para diretora da escola e chamar a mãe; chamo a mãe, passar..., falar o que está acontecendo, procurar saber se a mãe tem como encaminhar essa criança, se não tem como encaminhar nós procuramos a escola prá encaminhar a criança, que eu acho que, quando é necessário tem que ser colocado sim, tem que ser passado pra mãe, pra mãe estar a par, que a responsabilidade também é dela, e a continuidade da casa né, acho que tem que ser colocado sim.

B-26) Eu observo, eu trago sempre a questão pra R., eu acho que assim de imediato, é minha chefe e a diretora, procuro trazer pra ela esse problema, ela me orienta quanto a 
conduta em sala, eu tomo as condutas, se eu vejo que continua esse problema a gente sempre levanta em "HTC" essas dificuldades porque, às vezes, a experiência que eu tenho outro professor também já passou, traz alguma solução e vou...continuo investigando junto com a familia, junto com o grupo, e tentando trazer soluções e observando a melhora dessa criança, se há ou não essa melhora.

B-27) Não, não, primeiro eu passo prá... né, o meu superior, então sempre passo, converso com a turma, os professores... a equipe mesmo, e aí sim, se eles verem que há necessidade tudo, que a gente vai chamar a mãe pra estar conversando tudo né, conforme for a necessidade tem uma psicóloga da rede que tá sempre dando apoio pra gente, então é raro eu tomar partido logo de... sozinha, aí a partir do momento do que a gente tem aí sim você vai tentar né, porque também tem aqueles que você percebe que a dificuldade, às vezes da criança é na família, em casa, você tenta de uma outra maneira repor o que falta lá, né.

B-30) Como eu falei pra você, que eu estou a muito pouco tempo aqui na escola, ainda eu estou nesta fase né, que nem por exemplo: por enquanto eu só estou investigando pra eu ter um conteúdo, ter alguma argumentação pra justamente falar primeiramente, a gente tem que falar com o superior, então no caso teria que falar com a minha diretora..., com a orientadora pedagógica, primeiro me aconselhar com eles, até mesmo pedir observação delas né, da criança, pra não ser somente um parecer meu e, posteriormente juntas tomar uma atitudes, convocar o pai ou a mãe pra vim conversar... expor, ou qualquer outro tipo de atitude que venhamos tomar em conjunto. 


\section{Discurso do Sujeito Coletivo}

"Primeiro eu conversei com a escola, conversei com a minha direlora, passei para a coordenadora. A gente, também. conversa bastante com os outros professores, a gente costuma abrir para o grupo, porque o grupo tem experiência. A gente conversa para estar trocando idéias, é uma troca entre todos, discutindo no horário de trabalho coletivo, quando a gente reúne as professoras da manhã e as professoras da larde; mas assim de imediato, é minha chefe e diretora, a gente tem que falar com o superior."

Categoria C (Idéia Central) -"Veio indicada"

\section{Expressões-chave}

C-11.) Ela já é um criança que veio indicada, já é conhecida da escola, já até freqüentou quando era menorzinha, ela já freqüentou o "Amor Perfeito", ela é uma criança que faz acompanhamento com psicólogo.

C-18) Eu já estava ciente do problema né, já me passaram o problema ela veio com encaminhamento do neurologista.

\section{Discursos individuais}

C-11) Ela já é um criança que veio indicada, já é conhecida da escola, já até freqüentou quando era menorzinha, ela já freqüentou o "Amor Perfeito", ela é uma criança que faz 
acompanhamento com psicólogo, a mãe acompanha ela, ela é uma criança com acompanhamento, e aqui na escola eu fazia assim: eu tentava adaptar a situação, depende se fosse uma coisa que ela não conseguia a gente colocava sempre outro na mesinha, tinha alguém que ajudava, ou pra ela não sentir assim uma diferença: "eu não sei, eu me isolo, eu não vou fazer", sempre tinha assim... e os amigos eram muitos solidários, sempre estavam ajudando, não era tratada assim diferente, dava pra perceber assim porque a gente né... vê, e as crianças também sabiam que ela às vezes não conseguia mas ajudava, estavam sempre prontos ajudando, que eles estavam trabalhados... assim já foram trabalhados para ajudar. E eles conhecem ela, conheciam ela desde o começo, sabiam que ela tinha assim dificuldade, então eles ajudavam, porque a gente tem que trabalhar os colegas né, pra não discriminar. Você tem que trabalhar, assim entrosar e não percebia assim... ela não tinha nenhum constrangimento, ela se sentia a vontade até assim pra pedir ajuda.

C-18) Não, quando ela veio pra mim, eu já estava ciente do problema né, já me passaram o problema ela veio com encaminhamento do neurologista, e esta criança eh... segundo o neuro ela deveria freqüentar uma escola, onde as crianças fossem normais...Normais, né, uma criança numa escola normal, não uma classe especial, entendeu? Mas ela não acompanhava, ela não acompanhava, aí o que eu fazia: eu colocava uma cadeira perto da minha mesa, explicava a matéria pras outras crianças, e atendia individualmente a menina porque se ela ficasse na mesa dela, ela acabava rasgando as atividades dos outros, riscava, batia, entende, então não tinha como...; ou então levantava gritava, batia os pés, era um comportamento bem estranho, e depois no final do ano ai foi conversado 
com a mãe né, que se nós... até arrumamos uma escola onde tinha sala especial pra ela matricular, ela foi conversou com a diretora mas, ela não se conformou, ela acabou colocando na mesma...na nossa rede mesmo mas, na classe de crianças normais, não na sala especial mas, pelo que eu fiquei sabendo depois, ai ela tirou a menina da escola, no fim não sei que fim levou... não sei; mas eu acho que não

\section{Discurso do Sujeito Coletivo}

"Eu já estava ciente do problema e tentava adaptar a situaçâo, ela já veio indicada, já freqüentou o "Amor Perfeilo", é uma criança que faz acompanhamento com psicólogo e veio com encaminhamento do neurologista e segundo o neuro ela deveria freqüentar uma escola onde as crianças fossem normais."

Categoria D (Idéia Central) - "Não enfrentou problema"

\section{Expressão-chave}

D-10) Não.

\section{Discurso individual}

D-10) - Não, não. Não. 


\section{Discurso do Sujeito Coletivo}

"Não."

Categoria E (Idéia Central) - "Professor que tenta resolver o problema"

\section{Expressões chave}

E-1) Eu procurei entender e me aproximar.

E-2) Tentar resolver, primeiro momento, a gente.

E-3) Primeiro você vai tentar sozinha.

E-8) Fui falar com ele.

E-9) Eu não envolvi mais ninguém. Só fico olhando ele, nas informações sabe, como é que é a rotina dele diária.

E-12) Eu procuro resolver da melhor forma possível, em sala de aula.

E-13) Primeiro passo, a gente, tem todo tempo de observação.

E-17) A gente tenta dar conta na sala.

E-21) Primeiro faço o diagnóstico em sala.

E-25) Fui ler, fui buscar informações, e acho que esse é nosso trabalho, tambèm.

\section{Discursos individuais}

E-1) O que eu fiz? Eu procurei entender e me aproximar, entender porque ela agia assim e me aproximar... eu acho que a aproximação do professor, o contato fisico, o pegar a criança, o apoiá-la, deixar a criança muito próxima de você é muito importante pra criança, ela tem que saber que o professor tá ali. Não, porque nessa eu não vi 
necessidade, eu consegui resolver... né, então não teve necessidade, não foi um diferente assim... um caso tão grave ... complicado então não houve necessidade.

E-2) Bom, tentar resolver, primeiro momento, a gente...não vamos contar: olha... fazer todo um trabalho pedagógico, segundo momento: falei com minha diretora, expliquei o caso, ela veio contou com a gente ele..., às vezes, a gente tava contando $1,2,3,4, .5$, e ele imitava $1,2,3,4,5$, aí pedia prá ele contar no mesmo momento: $1,10,9,50$, e já... outro dia... é interessante... outros dias ele já conseguia seqüenciar até 5 , daí noutro dia ele já não conseguia mais seqüenciar até 5 . Assim era hum...daí, eu também... como ele passou prá $1^{a}$ série, chamei a mãe, eu pedi prá mãe tá tentando né, não taxando o filho dela porque a gente sentiu dificuldade, ele tinha dificuldade de se organizar também no espaço, com as coisas dele, engraçado que..., eu estive com ele no jardim 11 também, uma fase antes, assim... ele não conseguia copiar nada que você passasse, no pré ele conseguia copiar, pegar a palavra, em sequeencia e copiar, mas de todo o trabalho que a gente fez... assim: todas as crianças saíram sabendo o nome das letrinhas, ele conseguia copiar mas não conseguia nomear. E foi feito todo um trabalho prá nomeação dessas letras. Eu estive conversando com a mãe, daí eu não sei o que deu depois, porque aqui a gente não chegou a fazer encaminhamento prá essa criança aqui na escola.

E-3) Acho que tudo isso, primeiro você vai tentar sozinha, aí você vai tentar saber se realmente...aí você vai conversar com os colegas, você chama os pais, pergunta, acho que tudo. 
E-8) Eu lembro. Como era uma coisa muito notável, que aparecia muito, e as crianças..., as próprias crianças começaram a notar que o L. não queria fazer nada, só balançava, as crianças chamavam, ele não escuta professora, ele não escuta...Ah não! Gente, vamos ver o que ele tem, fui falar com ele, nada..., nada. Isso na primeira semana, daí eu comecei a falar com as colegas...vem ver gente, tem um aluno aqui que é meio diferente, acho que é diferente, vem ver, e na época eu era nova, também eu tinha pouco tempo de magistério. $O$ pessoal veio, olhou..., a dona da escola ficou um tempo na sala, então foi daí que se resolveu chamar a mãe. Primeiro todo mundo ficou vendo, sabendo, de como era a criança realmente, se sou eu a diferente ou se é a criança né, a gente tem que que ter essa idéia, então todo mundo notou que o garoto era muito diferente e foi chamada a mãe.

E-9) Por enquanto eu não pensei em nada disso. E uma coisa que me chamou muito a atenção, muitas vezes, isso acontece comigo, não sei se isso é positivo ou negativo, a gente recebe o relatório da criança no ano passado, né, do ano passado. Geralmente, eu ignoro aquilo, né? Eu não gosto de saber né, aquilo. Então a criança chega prá mim, eu começo a verificar como que ela tá nesse ano aqui. Eu coloco as minhas regras eu vejo como que ela recebe isso, e eu vejo o que quê tá acontecendo, então na classe. E, por enquanto eu não envolvi mais ninguém. Só fico olhando ele, nas informações sabe, como é que é a rotina dele diária. Então eu trabalho diretamente com a criança. Se eu não consigo isso, aí eu vou procurar ajuda, né. Mas no caso dele, eu observava, pegava na mão, pedia ajuda dos amigos, principalmente pra não falarem mal dele, não excluir 
mais ainda...e ontem eu nem fui pedir ajuda pra mãe, fui só verificar, já que eu sei que ele tem alguns problemas, só verificar como ele estava em casa, né

E-12) Eh...eu procuro resolver da melhor forma possivel, em sala de aula porque como eu trabalho numa comunidade que é bastante carente, muitas vezes eu chamo o pai, o pai nem pode tá presente na escola, porque ele não tem mesmo como faltar no serviço, muitas vezes não tem condições de ajudar a criança em casa, então a gente procura... e, eu procuro resolver em sala de aula, e pedindo ajuda também prás colegas de trabalho, que nem de manhã a gente troca muito, aqui a tarde a gente troca muito: ah! aconteceu tal coisa, né...que que vai..., uma ouve a outra dá opinião, raramente eu chamo os pais. Só em ultimo caso mesmo, quando a gente tentou todas as possibilidades, se for um caso assim por exemplo: de criança desatenta por indisciplina, alguma coisa assim..., quando é dificuldade eu procuro resolver em sala de aula .

E-13) É, primeiro passo, a gente tem todo tempo de observação se é isso mesmo, se é só com você, daí depois a gente parte..., traz pra cá, nós vemos acontecer, a gente compartilha, uma conta pra outra a dificuldade, né, vemos o que tá passando, aí a gente chama a mãe, conversa com a mãe, pra saber se em casa é também assim, e dai depois que a mãe conta, dependendo..., não foi o meu caso, mas foi o caso de outras professoras que chegaram a encaminhar.

E-17) Inicialmente, pra todos esses problemas que eu te falei, a gente tenta dar conta na sala, que a gente sabe que tem muita coisa aqui na escola, pros diretores pra outras 
pessoas tarem resolvendo, mas a familia é muito importante, antes de chamar o diretor pra qualquer coisa, eu converso com a mãe, se eu não consigo dar conta eu vou pra mãe, depois que eu levo pra ele.

E-21) Os três, primeiro faço o diagnóstico em sala, porque se ele tá fugindo a regra eu tenho que conversar com ele primeiro, pra saber porque...conversar sobre...especificamente com ele sobre o que ele pensa daquilo, se ele percebe que ele tá diferente dos amiguinhos, eu converso com ele. $\mathrm{O} \mathrm{J}$. não me respondeu, o $\mathrm{H}$. deu uma resposta toda desencontrada, você se acha diferente $H$.? E ○ V. me pegou: sabe assim uma resposta completamente desencontrada, conversei com a professora dele no passado, a R. H., ela me falou que ele era...tá melhorando muito, tá bem melhor e conversei com a mãe, perguntei como ele era em casa, a mãe dele falou que a única coisa que ele faz, que ele gosta de fazer, é ver tv ou ouvir radio, que também é alheio em casa, esse é o caso do $\mathrm{H}$, , o H. é assim completamente fora, então conversei com o corpo docente, com a direção com a familia e com ele. E o J. também, conversei com a mãe, porque ele é mudo aqui na escola, conversei com a mãe vi a situação da mãe, muito dificil financeira, o pai tá preso, ele sempre foi agressivo, sempre, depois que o pai foi preso ele tá piorando muito, não tem quem segure; a mãe inclusive..., sabe aquelas pessoas bem simples, não entendia porque. Ela não sabe porque, ela tem mais quatro filhos, todos ótimos, maravilhosos, apesar da situação financeira critica que ela se encontra, de não ter nem o que comer em casa. Ele não, ele é completamente diferente, ele tem assim um problema social muito grande, ele não socializa, não conversa, só agride, conversei também com a mãe, com a direção, como era novo não deu pra 
conversar com as professoras, né, porque esse periodo agora das dezessete todo aluno é novo aqui, ninguém tinha sala aqui, eles vieram de outras escolas, então não tem muito o que tá conversando com eles.

E-25) É uma característica minha, eu sou muito de tá falando, de tá questionando, de tá procurando, de tá lendo também, eu acho muito fundamental a gente tá lendo e pesquisar né, já aconteceu né, igual esse L. foi anos atrás, então fui atrás de uma instituição que ele acompanhava, da diretora, como lidar com essa criança, fui ler, fui buscar informações, e acho que esse é nosso trabalho também.

\section{Discurso do Sujeito Coletivo}

"No primeiro momento, a gente vai tentar resolver sozinha, tem todo o tempo de observação, a gente tenta dar conta em sala, faço o diagnóstico em sala. Eu procuro resolver da melhor forma possivel, procuro entender e me aproximar, o contato fisico, deixar a criança próxima de você é muito importante. Não envolvi mais ninguém, fico olhando como é a rotina diária dele, porque eu trabalho diretamente com a criança, se eu não consigo isso, ai eu vou procurar ajuda; muitas vezes, os pais nem podem estar presentes na escola, porque eles não têm como faltar no serviço. Então fui ler, buscar informações, porque esse também é nosso trabalho." 


\section{3 " PERGUNTA-"PARA QUE SERVE A TERAPIA OCUPACIONAL?"}

\section{Quadro sintese das idéias centrais}

A- "Não sabe"

B- "Ocupação do tempo"

C- "Ajudar pessoas com problemas"

Categoria A (Idéia Central) - "Não sabe"

\section{Expressões-chave}

A-4) Não tenho uma definição do que seja certamente.

A-5) Não tenho idéia do que seja

A-8) Eu não sei, mas já ouvi falar muito.

A-12) Não sei, não tenho conhecimento

A-14) Acho que pra adulto... ou pra criança ou pra quando você tem algum problema na vida, na familia, na escola, no trabalho, não sei, não tenho idéia.

A-17) Eu não sei.

A-19)...(silêncio)

A-20) Não sei te dizer.

A-22) Não sei.

A-23) Não, não sei. 
A-24) Eu queria saber...

A-25) Prá que serve a terapia ocupacional...? Nem...

A-28) Eu não sei porque não me debati com alguém que teve.

A-29) Não sei bem o que seria

\section{Discursos individuais}

A-4) Então, já ouvi falar, mas não tenho uma definição do que seja certamente.

A-5) Olha eu já ouvi falar, mas eu acredito que tera...não... eu tenho uma idéia assim...deve ser uma...uma coisa em grupo, não. Não tenho idéia do que seja

A-8) Para ser sincera, eu não sei, mas já ouvi falar muito.

A-12) Não sei, não tenho conhecimento.

A-14) Acho que pra adulto... ou pra criança ou pra quando você tem algum problema na vida, na família, na escola, no trabalho, não sei, não tenho idéia.

A-17) Eu não sei.

A-19)...(silêncio)

A-20) Não sei te dizer muito não. 
A-22) Não sei, já ouvi falar.

A-23) Não, não sei.

A-24) Ai que tá, eu queria saber...eu sei o termo terapia ocupacional, mas assim a fundo eu nunca cheguei ouvir falar.

A-25) Prá que serve a terapia ocupacional...? Nem...

A-28) Não é esse tratamento psicológico, que as pessoas vão pra conversar? Eu não sei porque não me debati com alguém que teve.

A-29) Bom, eu já ouvi falar né, não sei bem o que seria né, não sei muito bem, não.

\section{Discurso do Sujeito Coletivo}

"Para que serve a terapia ocupacional? Nem..., não tenho uma definição do que seja, não tenho idéia, não tenho conhecimento, eu não sei, eu queria saber." 
Categoria B (Idéia Central) -"Ocupação do tempo"

\section{Expressões-chave}

B-2) Uma forma de tratar as pessoas com ocupação

B-3) Prá ocupar o tempo com terapia?

B-10) Pra pessoa se ocupar?

B-16) Uma atividade pra o seu tempo, que seria um tempo assim ocioso, um tempo que não está fazendo nada.

B-21) Tornar seu tempo uma coisa útil.

B-30) Para a pessoa ocupar a sua mente.

\section{Discursos individuais}

B-2) Assim, eu imagino que seja uma forma de tratar as pessoas com ocupação, assim você dá uma ocupação ...é uma forma de tá tratando dos problemas dela: psicológicos, emocionais, fisicos.

B-3) Prá ocupar o tempo com terapia?

B-10) Pra pessoa se ocupar?

B-16) Olha pra que serve.....eh um terapeuta ocupacional geralmente eles... eles... ele é voltado pra determinados grupos, né, tanto pra idosos, enfim, que eles vão tá ..estar fazendo uma atividade pra o seu tempo, que seria um tempo assim ocioso, um tempo que 
não esta fazendo nada, geralmente grupos de terceira idade, tem a terapia ocupacional, porque geralmente nessa idade a pessoa... as pessoas se sentem não eh... largado, esse não é um termo correto, mas eles se sentem deslocado, eles se sentem fora, essa terapia ocupacional é pra tá colocando... pra ele tá se sentido... num grupo eh... como eles são importantes, né, não é porque eles deixaram de trabalhar... que ele não exerce uma importância na sociedade... acho muito interessante.

B-21) Ah! pra várias coisas, uma delas eu sei... uma delas eu sei: aliviar vocè de um problema que você tem, tornar seu tempo uma coisa útil, e fazer o que você gosta.

B-30) Prá que serve, eu acredito que seja pra ...para a pessoa ocupar a sua mente, seja ela aprendendo uma coisa nova, ou praticando uma coisa que ela já saiba fazer.

\section{Discurso do Sujeito Coletivo}

"Imagino que seja uma forma de tratar as pessoas com ocupação, ocupar o tempo com terapia e tornar seu tempo uma coisa útil; uma atividade para a pessoa ocupar sua mente seja aprendendo uma coisa nova ou praticando uma coisa que ela já saiba fazer." 


\section{Categoria C (Idéia Central) - "Ajudar pessoas com problemas"}

\section{Expressões-chave}

C-1) Prá crianças deficientes trabalhar a estimulação precoce, trabalhar a parte profissional dessas crianças deficientes.

C-6) A terapia ocupacional é uma forma da pessoa descobrir alguma deficiência que a pessoa tem, começar algum trabalho com essa pessoa.

C-7) Não diria dar atividades, mas sei lá... tentar... não seria atividades..., eu acredito que vocês fazem um trabalho prá modificar ou sei lá ajudar naquela dificuldade.

C-9) Prá orientar melhor essas crianças que tem ...crianças e pessoas que têm dificuldade em escrever, ou falar, ou pensar, ou depois que sofreu um acidente, organizar as idéias sabe? Acho que é uma espécie de psicólogo com fisioterapeuta, sabe, eu acho que é isso.

C-11) Ajudar a pessoa atingir aquilo que não conseguiu.

C-13) Ahnn, não sei, eu acredito que seja uma das formas, de tá resolvendo esses problemas ?...

C-15) Prá tá trabalhando mesmo esses momentos, criança mais agitada, ou aquele que tem alguma dificuldade motora.

C-18) A criança que não tem um bom desenvolvimento, que precisa de ajuda, eu acho que trabalha com isso.

C-26) Eu acredito que seja pra tá auxiliando justamente essas dificuldades de sala de aula, através da parte lúdica. 
C-27) Prá num caso desse pra ajudar, dando um apoio pra esse lado, né, nessas dificuldades dos individuos.

\section{Discursos individuais}

C-1) Pelo que eu sei pouco, era pra crianças deficientes trabalhar a estimulação precoce, trabalhar a parte profissional dessas crianças deficientes que... elas atingem um grau de aprendizado a nivel escola, aprendizado escrita, elas vão à terapia ocupacional e desenvolve outro tipo de trabalho, parte da oficina, também. O pouco que eu sei é isso.

C-6) Eu já ouvi falar, a terapia ocupacional é uma forma da pessoa descobrir alguma deficiência que a pessoa tem, começar algum trabalho com essa pessoa, acho que é uma forma de descobrir a própria pessoa se ela tem algum problema e porque tem.

C-7) Ah! Eu acho que vou falar um monte de besteira Cecilia, porque eu sou leiga no assunto, mas eu acho que seria um caminho prá resolver e tentar chegar a um determinado fim, justamente vamos supor, vamos falar em criança, minha área, adulto, sou leiga, mas vou tentar me expressar em termo de criança. Justamente crianças com casos diferentes, claro a gente não é ninguém prá tá avaliando, mas situações problemas diferentes, através da terapia tentar buscar o porque daquele caso estar ocorrendo, da criança ser daquela maneira, o que ocasionou aquele tipo de coisa. Não diria dar atividades, mas sei lá... tentar... não seria atividades..., eu acredito que vocês fazem um 
trabalho prá modificar ou sei lá ajudar naquela dificuldade, tentar ajudar. Realmente sou leiga, gostaria até que você me falasse depois.

C-9) Eu acho que ...ah é pra orientar melhor essas crianças que tem ...crianças e pessoas que tem dificuldade em escrever, ou falar, ou pensar, ou depois que sofreu um acidente, organizar as idéias sabe? Acho que é uma espécie de psicólogo com fisioterapeuta , sabe, eu acho que é isso.

C-11) Acho que pra, ajudar a pessoa atingir aquilo que não conseguiu, isso.

C-13) Ahnn, não sei eu acredito que seja uma das formas, de tá resolvendo esses problema?...

C-15) É pra... assim é pra tá trabalhando mesmo esses momentos, criança mais agitada, ou aquele que tem alguma dificuldade motora, acredito eu, me desculpe se eu tiver enganada, é assim atividades pra desenvolver mesmo esse lado, mas eu acho mais particular com cada um, coisa diferenciada da necessidade da criança.

C-18) Olha, terapia ocupacional é a que trabalha com esse tipo de criança, não é? Eu acredito que seja, né, que a criança que não tem um bom desenvolvimento, que precisa de ajuda, eu acho que trabalha com isso, não? A minha filha tinha vontade de fazer T.O., mas ela não se encaixava não, porque o negócio dela era dente, desde pequenininha ela tira os dentes dos priminhos, aí ela se encaixou em Odonto mesmo. 
C-26) Olha, eu nunca me aprofundei assim, prá saber né, mas eu acredito que seja pra tá auxiliando justamente essas dificuldades de sala de aula, através da parte lúdica.

C-27) Olha, eu tenho uma tia mesmo... no caso que... ela teve um derrame numa cirurgia, e ela tá fazendo...tá sendo acompanhada por uma terapeuta, né, porque ela... ela assim... era como se tivesse o motor de arranque dela não tá funcionando, você tem que tá dando umas empurradinhas pra ela tá, então a verdade eu acho que seria mais, eu não sei direito, não sei te dizer exatamente o que seria a terapia, mas eu acho que seria mais pra... pra num caso desse pra ajudar, dando um apoio pra esse lado, né, nessas dificuldades dos individuos.

\section{Discurso do Sujeito Coletivo}

"A terapia ocupacional é uma forma para orientar crianças e pessoas que têm dificuldades, ajudar a pessoa atingir aquilo que não conseguiu, também é uma das formas de estar resolvendo os problemas, começar algum trabalho com essas pessoas. Para estar trabalhando a criança mais agitada, ajudar aquele que tem dificuldade motora, dificuldade em escrever, ou falar, ou pensar, ou organizar idéias; ajudar a criança que não tem um bom desenvolvimento, estar auxiliando essas dificuldades de sala de aula. mais particular de cada um, através da parte lúdica. Trabalha 
a estimulação precoce para crianças deficientes e a parte profissional dessas crianças, dando apoio nas dificuldades." 


\section{5 - DISCUSSÃO}

\section{1 - A pergunta}

"Pra você o que é uma criança diferente?" É uma questão que tenta caracterizar a percepção do professor de educação infantil em relação ao seu aluno. A pergunta explora o conceito e o pré-conceito do professor frente ao aluno que se destaca na sala de aula. A pergunta tenta ainda, identificar o grau de reconhecimento do professor quanto a normalidade do desenvolvimento psicossocial e biológico da criança matriculada na escola de educação infantil.

O professor tem em suas mãos um cenário de observação singular e bastante consistente. Isto porque a escola é um local propício para a promoção de vínculos de afeto e trocas entre adultos e crianças, que incentiva a curiosidade, a percepção e exploração do ambiente e o contato com a cultura. Neste espaço existe a possibilidades de brincar, atividade privilegiada e reconhecida como vital para expressar emoções, sentimentos, pensamentos, desejos e necessidades. A interação entre todos esses conteúdos, proporciona à criança construir as bases fundamentais de sua educação inicial e permanente (NASCIMENTO, 2000). Desta forma, a escola de educação infantil é, ou pode se tomar, um espaço vantajoso para notar diferenças, e a pergunta ganha coerência neste contexto 


\section{2 - Notas sobre o diferente}

A percepção do diferente relaciona-se, também, com problemas "sem visibilidade", diferenças encobertas dentro da normalidade, isto é, o normal que poderá vir a apresentar problemas no âmbito da socialização e da dinâmica pedagógica. São, de maneira genérica, "problemas" que não são identificáveis através dos olhos do seu meio social de origem, no decorrer da vida cotidiana, anterior à escolarização. Estes "problemas" podem ser pistas relevantes, e afirma-se que as alterações que são/estão evidentes na idade de iniciação acadêmica, propriamente dita, podem ser evitados ou minimizados após a deteç̧ão precoce dos mesmos (MAGALHÃES e colaboradores, 1998).

Entre os problemas percebidos como diferenças, segundo a vivência profissional da pesquisadora, citam-se os alterações sutis de coordenação motora, socialização, comunicação, compreensão, auto-cuidado, atenção, direção e organização espaçotemporal. Os procedimentos de acompanhamento, assim como, de intervenção precoce, em tais casos, são significativos para evitar que estes problemas sejam "patologizados" e estigmatizem a criança (CORRÊA, 1990).

Ressalta-se que o reconhecimento das diferenças individuais pressupõe a experiência e a disponibilidade do observador, neste caso o professor de educação infantil, que pode agir no sentido inverso. Em outras palavras, o diagnóstico do professor é bastante significativo na cristalização do "rótulo" de criança diferente. 
Equalizar estas questões faz parte, na opinião da pesquisadora, dos preceitos do terapeuta ocupacional.

As conseqüências desta atuação resultam ou não, em melhor qualidade de vida para a criança, sua familia e para a comunidade. É pertinente ressaltar que os problemas de desenvolvimento e aprendizado são valorizados, em geral, apenas na idade de aprendizado acadêmico formal, o que reforça a importância da capacidade observacional do professor de educação infantil e de iniciação da escola fundamental, pois algumas pistas e até sintomas importantes, tendem a ficar encobertos pelo convivio de quem está próximo da criança, habitualmente a família. JIRIKOWIC e colaboradores (1997) salientam a importância das observações dos cuidadores e professores sobre saúde, comportamento e humor da criança. WALLEN e WALKER (1995) citam a importância da construção, pelo professor, de uma avaliação personalizada "não padronizada" voltada para as crianças em dificuldades na escolarização. Esta avaliação contemplaria, além da observação, entrevista com os pais, formulação de questionários com informações que incorporem aspectos da vida relacional do aluno.

A importância deste tema pode ser creditada pelo sentido negativo que encaminhamentos inapropriados ou, mesmo a falta dos encaminhamentos de crianças aos serviços de apoio, podem derivar. Nestes casos o prejuizo na vida relacional da criança é inestimável. Por outro lado, a importância deste estudo, indiretamente, pode ser alicerçada pelo seu lado positivo no sentido de que crianças corretamente encaminhadas e assumidas pelas instituições (escolas de educação infantil e serviços de 
apoio), tendem a se socializar e assim acompanhar o seu grupo etário e social, compensando eventuais problemas "reais". Além disso, é do senso comum entre os profissionais terapeutas ocupacionais, que crianças que freqüentam creches ou escolas de educação infantil, raramente, são encaminhadas para serviços de terapia ocupacional, particularmente em se tratando de rede pública de educação, sendo que na maior parte das vezes os encaminhamentos, nestes casos, restringem-se a presença de distúrbios evidentes, e patologias psico-neuro-motoras, por recomendação médica. Além disso, apesar dos recursos previstos e disponiveis, humanos e materiais, ainda é baixo o interesse dos governantes da rede pública em contar com profissionais da área de saúde como o terapeuta ocupacional, o que formaria um serviço de apoio condizente com as políticas de inclusão vigente no sistema de ensino brasileiro.

Registra-se ainda, neste campo, que nem toda formação do profissional de saúde inclui o conhecimento detalhado das características do desenvolvimento global da criança em idade escolar, do mesmo modo, a formação do educador, em geral, não contempla um contato mínimo com questōes de saúde, fazendo que o professor torne-se receptivo à difusão dos conceitos médicos em seus aspectos mais viciosos, sem as discussões incorporadas pela literatura (COLLARES \& MOYSÉS, 1985). O critério de avaliação do professor, segundo o trabalho de JACOB e colaboradores (1999) está sujeito a subjetividade. Considera-se a premissa de que a maneira como o ensino é conduzido na sala de aula, é reflexo direto das crenças e valores dos professores (CAVALCANTE, 2000). 
POLITY (2001) aborda a importância da "bagagem" pessoal, particularmente, do professorado e realça as influências dos múltiplos contextos, carregando para o exercício profissional seus referenciais pessoais e familiares. Segundo o mesmo autor, o trabalho com os alunos é desenvolvido e interiorizado pelo professor a partir da sua história de vida. Muitas vezes o professor se paralisa frente às dificuldades dos alunos, por não poder controlar as emoções suscitadas. Contudo, a aprendizagem é construída, em suas matrizes, a partir da interação da criança com adultos mais significativos, com outras crianças e objetos, por meio da exploração e da comunicação (NASCIMENTO, 2000). A escola de educação infantil tem, então, um caráter indispensável como espaço de desenvolvimento e aprendizagem, de contato entre crianças de faixa etária próxima, organizado intencionalmente para este fim, por um adulto significativo e cuidador, para norteá-las em periodo de tamanha importância e grandeza.

\section{3 - Comentando os achados}

Neste estudo, cinqüenta por cento dos professores tinham menos de trinta anos de idade, dado este corroborado pelo pouco tempo de magistério do grupo analisado. É possível que uma parte significativa dos conceitos e preconceitos nas respostas dadas por estes professores, sejam decorrentes da pequena vivência profissional no magistério. Estes aspectos são relevantes, pois é importante considerar que, em algum momento, muitas crianças experimentam dificuldades de aprendizagem e em função dessas dificuldades, acabam por ter necessidades educativas especiais (BUENO, 2001), 
necessidades estas, muitas vezes observadas à luz da experiência individual dos professores.

O estado civil e a idade parecem estar associados à estabilidade social dos individuos. Neste estudo, três quartos das professoras tinham um relacionamento estável sob esta ótica. Acrescenta-se a esta provável estabilidade, que metade das professoras são mães. Salienta-se ainda, outro aspecto importante, que é a de encontrar-se em uma amostragem probabilística apenas mulheres exercendo a profissão. Este fato está de acordo com a expectativa da função social de educar crianças pequenas ser vista, ainda, como atividade vinculada ao gênero feminino.

No tocante a preparação profissional das professoras, a maior parte delas optou por cursar a faculdade de pedagogia, contudo, um quinto das professoras não possuía qualquer formação de nivel superior. Esta situação coloca em evidência o enfoque eminentemente pedagógico da instituição escolar. A preocupação em especializar-se na área de pedagogia traduz o universo valoracional do ambiente de trabalho destas professoras, obviamente estimuladas por uma exigência institucional. Esta atitude parece refletir uma preocupação direcionada ao exercício da função, limitando-se, na maioria das vezes, às práticas pedagógicas e pouco atenta ao conjunto do processo de desenvolvimento para a formação do sujeito.

O trabalho de BRAGA (1995) lembra o conceito piagetiano de que o meio social influi no desenvolvimento cognitivo, portanto em sua teoria interacionista, parte do 
pressuposto que o desenvolvimento se daria a partir da interação de diversos fatores sócio-relacionais, onde o professor desempenha um papel central. Embasado nesta proposição pode se afirmar que a expectativa da "instituição escola" observadas neste estudo, e que subsidia/fundamenta o trabalho do professor é o rendimento do aluno, muitas vezes, não considerando a relação com o custo emocional da criança (JACOB e colaboradores, 1999).

Um dado que merece a atenção em relação aos professores entrevistados é o relativo ao seu meio familiar de origem no tocante aos seus antecedentes sócio-culturais. Neste aspecto chama atenção que dois terços dos professores entrevistados são filhos de pais de baixa ou nenhuma qualificação escolar. Se por um lado, a ascensão social que, estes professores entrevistados, foram protagonistas leva a valorizar o esforço individual dos mesmos ao longo do seu histórico de vida, por outro lado, é possível que com estes antecedentes, tais professores, cresceram à margem da expectativa cultural disponivel na sociedade contemporânea. Este contexto social e evolutivo, aparentemente deveria ser ponderado na análise dos determinantes das expectativas dos professores no tocante aos critérios de normalidade impostos aos seus alunos. Contudo, apesar de reconhecer estas associações, o presente trabalho não pretende avançar na análise destes determinantes.

Desta forma, ao analisar as categorias encontradas nos diversos discursos, percebe-se claramente a diversidade de opiniões, abordagens e propostas de soluções que não podem ser desvinculadas de toda esta matriz de origem das professoras. Não é de estranhar que a resposta para a primeira pergunta de alguns professores nâo leve em 
consideração que o aluno, muitas vezes, não esteja preparado para a "situação de escola". A "dificuldade de relacionamento" poderia ser creditada, com bastante facilidade, a não existência de periodo de adaptação e o não conhecer do professor e de seus amiguinhos. Esta situação pode fazer com que o aluno se torne tímido ou acentue a timidez dos que já o são. Julgar a diferença por esta ótica, parece ser uma tarefa extremamente imprecisa e tendenciosa. Da mesma forma, observar o relacionamento acentua a necessidade da instituição, ou até mesmo do professor, ter informação do contexto do aluno antes que este seja entendido como diferente. Vários sentimentos podem fazer o ser humano sentir-se intimidado: o medo, a insegurança, o desconforto. MULAS e colaboradores (1998) falam em dificuldades de ajuste social.

Por outro lado, responder que "todas são diferentes" parece encobrir a verdadeira opinião dos professores seja por insegurança em expor-se diante de um tema considerado delicado seja por omissão, ou seja ainda para assumir um papel politicamente correto. Neste sentido, as opiniões foram dadas de maneira em que a pessoa do professor não fosse exposta. Assumir a diferença faz, por vezes, que apareçam os conceitos, preconceitos e dificuldades na lida com os alunos, o que de alguma forma poderia ser inconveniente e impertinente para o cumprimento do papel profissional de professor de educação infantil pública, onde parece haver uma clara intenção de atender toda a gama de criança existente.

Uma parte dos professores também relaciona as diferenças de uma forma muito enfática com a idade das crianças, "Diferenças relacionadas à faixa etária" para estes 
professores significa o aluno atender a expectativa de sua idade cronológica. Entre estes professores parece estar sedimentada a visão "kronológica" do tempo, o tempo racional, do mundo externo, do relógio, o que em primeira instância é bastante importante mas não é a única forma de percepção do tempo. Muitas vezes deve ser considerado o tempo "kairós" que é um tempo interno, intuitivo, como cada um percebe ou trabalha no seu tempo, não no tempo da cultura latente. Sob outro ângulo é preciso destacar que os desajustes de faixa etária, também podem ser percebidos como sintomas antecedentes de distúrbios de aprendizagem (MULAS e colaboradores, 1998), porém deve-se considerar a possibilidade duma alteração passageira e transitória o que ocorre com muitas crianças antes de categorizá-las como diferentes.

Muito embora o compromisso da instituição escolar seja o de transmitir um conjunto de conhecimentos que possibilite ao aluno um bom desempenho social, a perspectiva de categorizar como diferente os alunos que "Não acompanha(m)" o processo de ensino/aprendizagem traz um risco de deslocar para o aluno (aprendizagem) a natureza de um processo interativo. Para os educadores, a habilidade do aluno em desempenhar tarefas escolares é a principal preocupação, sendo que, muitas vezes, os mesmos não se atentam para o real problema do aluno (KEMMIS \& DUNNN, 1996). Da mesma forma, não corresponder às expectativas da escola é um dos sintomas mais evidentes de déficit circunstancial (MANTOAN,1997). Percebe-se, muitas vezes, que questões de caráter pedagógico tornam-se grandes debates e questões de saúde. Este tema é tão contundente que CARRARO (1999) fala do "tema" da deficiência de não 
acompanhar as aulas. Entre os professores entrevistados e classificados nesta categoria, a profissão parece ser a intersecção entre estes dois momentos.

Por outro lado categorizar os alunos embasados por critérios de "Aparência fisica" conduz à "biologização" do psicossocial, dado que esta abordagem associa imediatamente a diferença com a imperfeição física e mental. Em que pese muitos alunos diferentes terem, realmente, problemas mentais, a redução de tão variado espectro a um ponto tão específico não reflete a disponibilidade dos professores em aceitar e trabalhar para resolver o problema destes alunos.

O mesmo comentário pode ser subentendido quando se "associa as diferenças à presença de deficiência", categoria F para a primeira questão. Neste sentido, o trabalho de BRAGA (1995) aponta para o fato de que uma criança cujo desenvolvimento esteja prejudicado por um defeito ou seja portador de uma necessidade especial, não é uma criança menos desenvolvida que seus pares. Esta criança desenvolve-se de maneira diferente. Independentemente da ótica em que se desdobre a discussão, a condução do processo pedagógico do portador de deficiência é algo que deveria ser trabalhado na formação do professor de educação infantil.

No âmbito, "Associados a comportamentos destoantes", MULAS e colaboradores (1998) tratam de diferentes: déficits: comportamental, sócio-relacional, motor, e auto-cuidado. Certa ênfase, no que diz respeito aos "comportamentos destoantes", vem sendo dada a questão da agressividade, sempre percebida, apenas, 
como negativa. Quando uma criança é abertamente agressiva ou esquiva ou não aprende a ler supõe-se que a causa esteja mais na criança do que nas condições a ela oferecidas, o problema é a criança (REGER, 1981). Sem questionar o "tipo" de agressividade declarada, deve-se reportar ao trabalho de JACOB e colaboradores (1999) onde é salientado que a agressividade é um traço fundamental para a aquisição do conhecimento e possivelmente, um dos fatores que favorecem o bom desempenho acadêmico, na medida em que esta é utilizada na incorporação do conhecimento. Os autores citam ainda, que na tentativa de satisfazer as demandas externas, pelo esforço da subordinação, a agressividade, enquanto impulso criativo, passa a ser contida em si, cerceando a criatividade manifestando-se de forma defensiva. Entre os encaminhamentos dos professores é comum o de associa-los a temperamentos pouco compativeis com as exigências escolares, "latu senso".

"Associado ao modelo familiar", categorização que adjetiva a diferença como negativa, qual seja a criança é a resultante social do seu grupo familiar de origem. Os professores deslocam a criança como indicador do grupo social e fazem digressões entrando explicitamente no campo de juízo de valores. Neste contexto, OLSON e colaboradores (1990) falam da importância do meio familiar na formação dos processos de cognição da criança. Este fator relaciona-se com os aspectos afetivos do meio social de origem. A qualidade dos vinculos associa-se também com a capacidade de autocontrole da criança. O meio social interfere na percepção e entendimento dos signos (BRAGA, 1995). 
Neste universo de conceitos valorativos busca-se em seguida, por meio das respostas à próxima pergunta, identificar as principais atitudes dos professores frente às crianças que no seu entender eram diferentes: "O que você fez quando estava diante da criança diferente?"

A sintese dos discursos da primeira categoria foi "Socorro familiar", ou seja, para os professores que assim responderam, a busca de soluções deve ser feita fora da instituição, indiretamente isentando-a. Fica claro, nesta categoria, a falta de interação entre as partes envolvidas. Contudo a aprendizagem é fruto da transacionalidade, da relação, do afeto, no sentido em que inclui os dois envolvidos: quem aprende e quem ensina. Esta (a aprendizagem) é dialética e complexa - sistêmica e linear. No caso da criança que fracassa, a escola, que em principio deveria prover mecanismos protetores, aparece como instância que contribui para aumentar a vulnerabilidade frente a riscos, particularmente no ponto de vista da transição que caracteriza o ingresso no ensino formal (MARTURANO, 1999).

É evidente que para boa parte dos professores a busca de alternativas para o enfrentamento de situações destoantes, seja no processo pedagógico, seja no processo interpessoal entre o professor e o aluno, deve partir da instituição, "socorro institucional". Contudo a instituição tem regras de conduta muito pouco claras no tocante a situações que fogem ao cotidiano. Muitas crianças experimentaram dificuldades e têm, portanto, necessidades educativas especiais em algum momento de sua escolarização. Assume-se, pois, que as diferenças humanas são normais e 
necessárias e que a aprendizagem deve se adaptar às necessidades da criança, ao invés de se adaptar a criança e assunções pré-concebidas pela instituição (BUENO, 2001). Embora adequada a um compromisso histórico da instituição, há de se realçar a preocupação ética quanto aos direitos da criança, no que tange a confidencialidade e privacidade de suas dificuldades que podem se desdobrar de forma negativa em seu futuro (ECA, 1992).

Uma das situações encontradas nesta pesquisa diz respeito àquelas crianças que são encaminhadas para as escola mas, com um parecer anterior sobre sua condição: "Veio indicada". Naturalmente há uma expectativa por parte daqueles que encaminharam, de que a escola, enquanto instituição, tenha pré-definido um conjunto de procedimentos padrões capazes de responder a esta demanda. Nesta situação, alguns professores assumem uma atitude passiva corroborando o encaminhamento, e aceitando a "diferença observada pelo olhar do outro" sem crítica ou iniciativa, de reconfigurar (diagnóstico, orientação e tratamento) o problema. Passividade esta que segundo LEE e colaboradores (1998) terá impacto inquestionável no relacionamento entre a criança, professor e escola.

Cabe realçar a presença de uma professora que "Nunca enfrentou o problema". Embora possa ser caracterizada como uma resposta pouco comum no conjunto das professoras entrevistadas, é uma situação que merece comentário. Em primeiro lugar, a idade média das professoras deste estudo, foi de 31 anos e, acresce-se a isto, que cerca de 2/3 delas tinham menos de 10 anos de magistério. Contudo, não ter enfrentado o 
problema, pode representar a não percepção de uma situação com diversas possibilidades de explicação.

Finalmente é importante salientar que uma parte das professoras, enfaticamente, "tenta(m) resolver o problema". Aparentemente estas professoras em consonância com MANTOAN (1997) acreditam que o papel do professor é encarar o desafio do diferente, tomando para si além da função de sistematizar o saber, ajudar o aluno instrumentalizando-o para adaptação ao meio em que vive e ajudá-lo a transformar esse meio em um lugar melhor. O professor de educação infantil tem, também, um papel bastante diferenciado dentro do sistema de cuidados da criança em desenvolvimento. Desenvolvimento este que não pode ser desarticulado do processo de aprendizagem por serem interativos (GÓES, 1991),. Deste modo percebe-se que um processo interpessoal é transformado num processo intrapessoal (VELOSO \& PINTO, 1993). LORDELO (1998) salienta o papel diretor do adulto em apoiar e estimular o desenvolvimento da criança nas áreas cognitiva, social e emocional. Torna-se importante realçar a importância do adulto/educador cuidador tanto para a integridade do desenvolvimento, como para a superação de situações adversas (resiliência) na vida da criança, considerando que este adulto faça parte do ambiente facilitador (MORAES, 1997; MORAES \& RABINOVICH, 1996).

Embora esta "atitude acolhimento" de respeito a individualidade das crianças seja resultado de uma expectativa profissional ela se desenvolve entre professores de maneira ansiosa, analógica e desordenada. Corre-se o risco de transferir ao docente a 
responsabilidade do gerenciamento e decisão do futuro de cada criança. Face ao universo sócio-cultural do professor é possível que a compreensão dos comportamentos "diferentes" seja objeto de reeducação no sentido da moralização e domesticação, não permitindo um acesso à cultura disponivel na sociedade moderna (MACHADO \& SOUZA, 1997). Por vezes, percebe-se que a criança não apresenta o comportamento esperado pela professora como ficar sentado quieto, fazendo lições e obedecendo ordens. Muitas vezes, são crianças normais, apresentando uma gama diversa de comportamentos esperados para a idade, e outras vezes, relativo a situações de escola, que são aborrecidas e até desrespeitosas, considerando o público atendido.

O professor é afetado pelo fracasso/dificuldade de seu aluno e, por vezes, pouco informado acerca dessas dificuldades, recorre a métodos mais exigentes, chegando em alguns momentos até a punições. Diante do insucesso das providências adotadas, pode deixar de se empenhar e passar a se desinteressar (COELHO, 1992). Contudo, há alguns professores que, direta ou indiretamente, conscientes de suas limitações, encaminham essas crianças para outros serviços de apoio. Neste trabalho procurou-se explorar o conhecimento desses docentes no tocante aos serviços de terapia ocupacional. Assim, imediatamente após a contextualização das diferenças entre alunos das classes de educação infantil, perguntou-se ao professor "Para que serve a terapia ocupacional?"

A concepção prevalente entre os professores, está associada à categoria "Não sabe". De maneira óbvia, esta categoria resume a falta de conhecimento com a terapia ocupacional. Contudo, a alta prevalência (mais de cinqüenta por cento) impõe algumas 
reflexões. A primeira delas remete à própria história da terapia ocupacional em nosso meio. Somente a partir da década de 50 ela chega ao Brasil e oficializa-se nos anos 60, mesmo assim, tratada como profissão de caráter mais benemerente do que técnico. A partir de meados dos anos 60 a terapia ocupacional começa a se mostrar como "profissão da saúde", e desta forma, amplia-se nos anos 70 quando algumas universidades abrem cursos. Outra consideração diz respeito ao próprio amadurecimento dos marcos teóricos da terapia ocupacional. A partir de experiências com doenças incapacitantes da medicina de reabilitação do trabalho, o leque de vivências, vem se ampliando atingindo outros grupos de risco, como crianças e idosos. A falta de acesso a informações atualizadas nos grandes centros acadêmicos, aliada à falta de divulgação direcionada ao esclarecimento sobre suas reais potencialidades e competências justifica uma boa parte do desconhecimento dos professores entrevistados assim como, provavelmente, do público em geral.

Por outro lado, há ainda alguns professores que relacionam a utilidade da terapia ocupacional com "Ocupação do tempo". Neste caso parece que esta opinião estaria associada aos primórdios dos preceitos da terapia ocupacional. Usar o tempo de forma considerada útil constitui-se, ainda hoje, em recomendações de saúde em seu sentido mais amplo: o homem e sua atividade, sua independência, sua produção, sua práxis. Além disso, é fácil associar a idéia de ocupação do tempo no sentido de aproveitar o potencial das pessoas, independentemente da faixa etária a que pertençam. 
Para esta última pergunta, um grupo relativamente pequeno de professores reconhece a utilidade da terapia ocupacional, de forma rudimentar, em "Ajudar pessoas com problemas"...

De fato, desde 1992, KRANOWITZ defende a ampliação do papel da terapia ocupacional voltando-se a recuperação do curso de vida das pessoas, que tivesse sido interrompido, não só por processos mórbidos, acidentais ou, ainda, mudado pelo envelhecimento, como também para outras situações mais leves que comprometam a vida relacional dos indivíduos. Defende sua utilização em crianças saudáveis, mas com quadros motores ou psico-afetivos sutis, para melhorar o desempenho na vida prática e diária, no sistema de educação infantil e na escola fundamental.

Neste contexto discursivo e temporal percebe-se que as dificuldades em definir a relação ensino/aprendizagem distanciam-se da simples tipificação da relação interpessoal entre professor e aluno (VYGOTSKY e colaboradores, 1998). Envolve o histórico sócio-cultural dos professores, as circunstâncias de vida e trabalho de cada um, os preconceitos e o conhecimento acerca do desenvolvimento da criança, disponibilidade de instrumental técnico-científico e das possibilidades de intervenção no sentido de valorizar ou, pelo menos preservar o potencial de desenvolvimento da criança da classe de educação infantil, lembrando-se que são sujeitos históricos contextualizados e inacabados. 


\section{6 - CONSIDERAÇÕES FINAIS}

O presente trabalho evidencia que o grupo de professores entrevistados têm uma origem homogênea que é bastante peculiar. Maciçamente, trazem na bagagem uma história de vida associada à pobreza e que, por méritos próprios, ascenderam socialmente. São na maioria jovens e com pouco tempo no exercício do magistério. Contudo, apesar destas características, apresentaram um material discursivo extremamente diversificado e consistente. Ao longo das entrevistas pôde se perceber o empenho mostrado e o comprometimento com a profissão e, apesar desta amostra ser representativa do universo de trabalho de uma região da Grande São Paulo, é bem possível que a realidade encontrada ultrapasse os limites da região estudada.

A opção por trabalhar-se com a análise do discurso do sujeito coletivo, segundo o proposto por LEFÈVRE (2000) permitiu uma categorização didática do pensamento do professor, validando esta metodologia dentre as possibilidades de análise nas pesquisas qualitativas. E se por um lado a metodologia empregada não apresenta um ângulo de abordagem pré-determinado, por outro, permitiu a pesquisadora analisar de forma, relativamente, rápida e aprofundada um número expressivo de discursos, o que em termos estatísticos significa dar consistência externa neste tipo de estudo.

Um aspecto refletido para a concretização deste estudo foi a importância da dialética interativa do processo ensino/aprendizagem, que não pode estar desarticulado 
do desenvolvimento e do momento histórico pela qual passa a sociedade. Porém destacase que, apesar desta compreensão, o aluno não foi contemplado neste estudo, o foco foi, exclusivamente, o professor de educação infantil - o ângulo do educador -

Dentro de uma sociedade extremamente competitiva e consumista, como a contemporânea, famílias e escolas dirigem seus esforços no sentido de tornar as crianças cada vez mais capazes para sairem-se bem no futuro. Esta cobrança inicia-se, cada vez mais, em idades precoces. É necessário repensar o papel da educação infantil (SCHWARTZMAN, 1992).

Face a esta argumentação torna-se imprescindivel pensar nas crianças que apresentam ou podem vir a apresentar diferenças que as impeçam de ser ou estar perfeitamente inseridas no grupo dominante. Observa-se que as diferenças em crianças, nas idades mais tenras, são diagnosticadas pela familia e pela escola. Diante de tal quadro entende-se a relevância do papel do professor de educação infantil. O que ele percebe como diferente.

A pesquisa revelou que existe a capacidade diagnóstica do professor de educação infantil. Múltiplos comportamentos nas crianças, muito sutis, são percebidos como diferença entre os professores. As percepções são bastante pertinentes e consoantes com os escritos. O professor mostrou que a capacidade diagnóstica obedece a critérios. Considera-se que estes critérios seguem um padrão relacionado às exigências 
pedagógicas, porém dentro de um sistema estabelecido onde a individualidade da criança, às vezes, parece não ser relevada. Durante toda a discussão procurou-se trabalhar com os contra-pontos das respostas/opiniões dos professores; não no sentido de discordar ou destituir a condição e a competência do professor mas, para mostrar que existem outras premissas, lógicas e formas de olhar.

O enfrentamento do problema da criança diferente trouxe como questão a não existência de um padrão de resolução dentro deste universo. Abre-se um espaço para destacar que não há orgulho em dizer que uma determinada criança foi encaminhada corretamente para um serviço de apoio quando o atraso é evidente. Há por outro lado, coerência quando investiga-se a tempo de prevenir conseqüências futuras, estimulando tanto as aquisições de conhecimento/informação como uma satisfatória convivência social, crianças no limite entre o patológico e o normal.

Existem procedimentos de todas as linhas: o professor que vê o problema fora de sua circunstância e circunscrição transferindo-o somente para a família, o que apela para o socorro institucional gabaritando a direção da escola como instância capacitada na resolução dos problemas das crianças, que geralmente aparecem dentro da sua sala, e as que tentam, solitariamente dar uma resposta em sala, sem interferência da família e da escola, tomando para si a responsabilidade de solucionar o problema. A dificuldade está em não saber o que fazer com correção e segurança. 
Não se pode desagregar as observações dos professores da situação real da rede de apoio às suas instituições. É sabido que há uma carência de profissionais especializados em desenvolvimento infantil que permita a estes professores se reportar, em caso de dúvida ou mesmo certeza, quando as alterações da criança são óbvias.

Percebe-se, claramente, a falta de um sistema de suporte que viria a contribuir com o trabalho do professor e com as necessidades das crianças. Este sistema não seria para interferir no trabalho, único e exclusivo, do professor de ensinar mas, o subsidiaria em sala no sentido de minorar as dificuldades da criança.

Neste sistema de apoio, se incorporaria o terapeuta ocupacional, que junto ao professor construiria um modelo interdisciplinar voltado para aquisições relacionadas ao complexo aprendizagem/desenvolvimento, numa fase em que a criança tem melhores condições de superar dificuldades. O processo de Terapia Ocupacional, na escola em colaboração com outros profissionais e família é apontado como fator importante no que diz respeito a ajudar crianças em dificuldades (HANFT \& STRIFFER, 1995). A complexidade do fator desenvolvimento deveria ser contemplado por aspectos multi e interdisciplinares voltados para a integralidade da criança.

No que tange as respostas sobre terapia ocupacional e suas atribuições, afirma-se, de forma contundente um desconhecimento, quase total, que mostra a necessidade de um intenso trabalho de divulgação junto aos professores de educação infantil e na própria rede pública. Isto ocorre, também, em face da rede pública estudada não contar com este 
profissional em seus quadros. Como o professor de educação infantil pode conhecer o trabalho de um profissional que não existe? Sabe-se que existe a disponibilidade deste profissional no mercado de trabalho, aproveitá-lo dentro deste contexto seria decisivo. MOLINEAUX \& MATTHEW (1993) apontam a importância da consultoria em terapia ocupacional nos ambientes naturais da criança, entre eles, a escola.

Uma proposta a ser viabilizada a partir desta pesquisa é a elaboração de uma oficina com os professores das escolas públicas de educação infantil do Município de Taboão da Serra sobre algumas possibilidades de trabalho do terapeuta ocupacional na rede.

Cabe realçar que este trabalho aborda, sob a perspectiva do desenvolvimento da criança, a importância da percepção e capacitação do professor e todas nuances dos desdobramentos possíveis desta interação impactante. Longe de esgotar esta discussão é preciso dar continuidade a este trabalho, dado que, pesquisa-se sujeitos e situações históricas em construção.

Salienta-se que esta pesquisa partiu da valorização da percepção do trabalho do professor de educação infantil na condução do processo pedagógico. Este é o primeiro elo para a apropriação da cultura, o que fará com que o sujeito seja um cidadão. Para tal, o professor deverá estar instrumentalizado. Esta instrumentalização passa pela própria formação do professor de educação infantil que é assimétrica no que diz respeito entre o seu poder e o do seu aluno. Existe um trabalho além das letras e dos números, um 
espaço, um ponto...Um ponto em que o professor de educação infantil, e por vezes, só ele é capaz de ver e perceber.

Reconhece, uma vez mais, desde o início, as dificuldades que o sistema educacional tem de lidar com situações diferentes e, preocupa-se ao longo deste trabalho, com a sabedoria do professor que mediada por valores pessoais é capaz de decidir quem são os diferentes e os normais. Um profissional, em atual processo de desvalorização, que merece todo o respeito e deferência. A quem todos que chegam a academia devem o maior respeito e, maciçamente, afeto. 


\section{7 - REFERÊNCIAS BIBLIOGRÁFICAS}

Araújo SMM. Considerações sobre limites e possibilidades da proposta de Emília Ferrero aplicada à escolaridade inicial. Temas sobre Desenvolvimento 1996; 5(29):326.

Ariès P. História social da criança e da familia. Rio de Janeiro: Zahar; 1981.

Ayres AJ. Sensory integration and the child. 3rd ed. Los Angeles: WPS; 1980.

Bowlby J. Apego. São Paulo: Martins Fontes; 1984.

Braga LW. Cognição e paralisia cerebral: Piaget e Vygotsky em questão. Salvador: SarahLetras; 1995.

Brasil. Constituição: República Federativa do Brasil. São Paulo: Imprensa Oficial do Estado; 1988.

Brasil. Lei de Diretrizes e Base da Educação Nacional (LDB) - Lei 9394. Diário Oficial da República Federativa do Brasil - Brasilia (DF), 20 de dez 1996.

Bueno JGS. A inclusão de alunos deficientes nas classes do ensino regular. Temas sobre Desenvolvimento $2001 ; 9(54): 21-7$.

Bundy AC, editor. Making a difference: OTs and PTs in public schools. Chicago: University of lllinois; 1991. 
Carraro LF. Entre fogos cruzados: a criança de classe especial como produto da percepcāo dos atores institucionais envolvidos. São Paulo; 1999. [Dissertação de Mestrado - Faculdade de Saúde Pública da USP].

Carvalho LF. Terapêutica ocupacional. Rev Paul Hosp 1953; 1(8): 19-21.

Cavalcante RSC. A inclusão do aluno com necessidades educacionais especiais na sala de aula do ensino regular: o papel do professor. Temas sobre Desenvolvimento 2000; $9(52): 31-5$

Coêlho ASBF. Distúrbios da aprendizagem escolar: a intervenção psicopedagógica. Temas sobre Desenvolvimento $1992 ; 6: 18-9$.

Collares C, Moysés MA. Educaçāo ou saúde? Educaçāo e saúde? Educaçāo e saúde! Porto Alegre: Cortez; 1985.

Corrêa MAM. De rótulos, carimbos e crianças nada especiais. Campinas; 1990 [Dissertação de mestrado - Faculdade de Educação da UNICAMP].

Ferriani MGC, Gomes R Saúde escolar: contradiçōes e desafios. Goiânia: Cultura e Qualidade; 1997.

Góes MC. Natureza social do desenvolvimento psicológico. Cad Cedes; 1991:17-24.

Gonçalves W. Taboão da Serra: sua história e sua gente. São Paulo: O Pirajuçara Jornal; 1994. 
Hanft B, Striffler N. Incorporating developmental therapy in early childhood programs. Infant Young Child 1995; 8(2):37-47.

Hopkins HL. An historical perspective on occupational therapy In: Hopkins HL, Smith HD. Willard and Spackman's occupational therapy. 5th ed. Philadelphia: J B Lippincot Company; 1978. p. 3-23.

Jacob AV, Loureiro SR, Marturano EM, Linhares MBM, Machado VLS. Aspectos afetivos e o desempenho acadêmico de escolares. Psicologia: teoria e pesquisa 1999; 15:153-62.

Jirikowic TL, Engel JM, Deitz JC. The test of sensory functions in infants: the test-retest reliability with developmental delays. Am J Occup Ther 1997; 51:733-8.

Kemmis BL, Dunn W. Collaborative consultation: the efficacy of remedial and compensatory interventions in school contexts. Am J Occup Ther 1996; 50:709-17.

Kramer SA Educação ou tutela? A criança de 0 a 6 anos. São Paulo: Loyola; 1988.

Kranowitz CS. Catching preschoolers before they fall: A developmental sreening by Carol Stock Kranowitz. Child Care Inf Exch 1992; 84:25-9.

Lee VE, Loeb S, Lubeck S. Contextual effects of prekindergarten classrooms for disadvantaged children on cognitive development: the case of chapter 1. Child Dev $1998 ; 69: 479-94$ 
Lefèvre F. A importância da creche para o processo de inserção social e para o ingresso da criança na cultura. Rev Bras Cresc Desenv Hum 1994; 4:57-9.

Lefèvre F, Lefèvre AMC. Recuperando a fala do social. São Paulo: FSP/USP/HSP; 1998. (EIXO Promoção de saúde. Série Monográfica, 9).

Lefèvre F, Lefèvre AMC. $O$ discurso do sujeito coletivo: uma nova abordagem metodológica em pesquisa qualitativa. São Paulo; 1999.[Apostila de Difusão Cultural -Faculdade de Saúde Pública da USP].

Lefèvre F, Lefèvre AMC, Teixeira JJJ, organizadores. $\mathrm{O}$ discurso do sujeito coletivo: uma nova abordagem metodológica em pesquisa qualitativa. Caxias do Sul: Educs; 2000.

Lefèvre AB. Exame neurológico evolutivo do educação infantilr normal. São Paulo: Sarvier; 1972.

Lopes RE. A direção que construimos: algumas reflexões sobre a formação do terapeuta ocupacional. Rev Ter Ocup Univ São Paulo 1993/6; 4/7:27-35.

Lordelo ER O papel do aulto e da criança como parceiros do desenvolvimento em Vygotsky. Rev Bras Cresc Desenv Hum 1998; 8 (1/2):26-32.

Machado AM, Souza MPR, organizadores. Psicologia escolar: em busca de novos rumos. São Paulo: Casa do Psicólogo; 1997. 
Magalhães LC, Barbosa VM, Paixão ML, Figueiredo EM, Gontijo APB. Acompanhamento ambulatorial do desenvolvimento de recém-nascidos de alto risco: características da população e incidência de seqüelas funcionais. Rev Paul Pediatr $1998 ; 16: 191-6$

Mantoan MT. Ser ou estar: eis a questão. Explicando o déficit intelectual. Rio de Janeiro: WVA; 1997.

Marturano E Recursos no ambiente familiar e dificuldades de aprendizagem escolar. Psicol Teor Pesq 1999; 15:135-42.

Mialaret G. A educação educação infantilr no mundo. Lisboa: Moraes; 1976.

Minayo MC. $\mathbf{O}$ desafio do conhecimento: pesquisa qualitativa em saúde. São Paulo: HUCITEC/Rio de Janeiro: ABRASCO; 1996.

Molineux M. Improving home programme compliance of children with learning disabilities. Aust Occup Ther J 1993; 40:23-32.

Moraes MCL. O retardo de crescimento intra-uterino/prematuridade/baixo peso ao nascer e suas possíveis conseqüências: danos neurológicos evidentes e danos neurológicos não evidentes. Rev Bras Cresc Desenv Hum 1995; 5:96-103.

Moraes MCL, Rabvinovich EP. Resiliência: uma discussão introdutória. Rev Bras Cresc Desenv Hum 1996; 6(1/2):10-3. 
Moraes MCL. Aspectos de saúde na rotina da creche e o papel do cuidador da criança: relato de experiência. Rev Bras Cresc Desenv Hum 1997; 7:87-92.

Mosey AC. Terapia ocupacional: uma perspectiva histórica. III Envolvimento no movimento de reabilitação. Campinas; 1979.[Apostila do Curso de Graduação em Terapia Ocupacional da PUCCAMP].

Mulas F, Morant A, Rosseló B, Soriano M, Ygual A. Factores de riesgo de las dificultades en el aprendizaje. Rev Neurol 1998; 27:274-9.

Nascimento, MPL. A importância da educação infantil para o desenvolvimento infantil. Temas sobre Desenvolvimento 2000; 9:65-7.

Olson SL, Bates JE, Bayles K. Early antecedents of childhood impulsivity: the role of parent-child interaction, cognitive competence and temperament. J Child Psychol 1990; 18:317-34.

Patto MHS. Introdução à Psicologia Escolar. São Paulo: TA Queiroz; 1989.

Polity E. Repensando o educador à luz do modelo sistêmico. Temas sobre Desenvolvimento $2001 ; 9(54): 58-9$

Reger R. Psicólogo escolar: educador ou clínico? In: Patto MHS, organizadora. Introdução à psicologia escolar. São Paulo: TA Queiroz; 1981.

Rollet-Echalier C. La politique a légard de la petite enfance sous la IIle republique. Paris: Institute National D'Etudes Demographiques/PUF; 1990. 
Rosemberg F, Campos MM, Pinto RP. Creches e educação infantils. São Paulo: Nobel/Conselho da Condição Feminina; 1985.

Rossetti-Ferreira MC, Mello AM, Vitoria T, Gosuen A, Chaguri AC Os afazeres na educação infantil. $2^{\mathrm{a}}$ ed. São Paulo: Cortez; 2000.

Schwartzman JS. A criança com dificuldades na escola. Temas sobre Desenvolvimento $1992 ; 7: 19-25$.

Schwartzman JS. A criança com distúrbios escolares: aspectos neurológicos. Temas sobre Desenvolvimento $1994 ; 8: 4-11$.

Siqueira AAF, coordenador. Estatuto da criança e do adolescente: planilha para operacionalização. São Paulo: Centro de Estudos do Crescimento e Desenvolvimento do Ser Humano/ CBIA; 1992.

Soares LBT. Terapia ocupacional lógica do capital ou do trabalho? São Paulo: Hucitec; 1991.

Sousa AMC. Educação infantil: uma proposta de gestão municipal Campinas: Papirus; 1996.

Spitz RA. O primeiro ano de vida. São Paulo: Martins Fontes; 1991.

Stephenson E, Mckay C, Chesson R. The identification and treatment of motor/learning difficulties: parents'perception and the role of the therapist. Child Care Health Dev $1991 ; 17: 91-113$. 
Veloso AF, Pinto SAM. Distúrbios de aprendizagem: diagnóstico e orientação. Temas sobre Desenvolvimento $1993 ; 3: 10-3$.

Vieira LMF Mal necessário: creche no Departamento Nacional da Criança. Cad Pesq $1988 ; 67: 3-6$.

Vygotsky L, Luria A, Leontiev A. Linguagem, desenvolvimento e aprendizagem. São Paulo: Cone, 1988.

Wallen M, Walker R. Occupational therapy practice with children with perceptual motor dysfunction: findings of a literature review and survey. Aust Occup Ther J 1995; $42: 15-25$.

Forum Metropolitano de Segurança Pública. Taboão da Serra: perfil [on line] Disponíve] em URL: http:// www.forumsp.org.br/perfil taboão da serra.htm [2002 jan 20]. 
ANEXO I

Questionário/Entrevista 


\section{IDENTIFICAÇÃO DO ENTREVISTADO}

Ficha $n^{\circ}$

Data da entrevista.

Nome do Professor.

Data de nascimento

Idade

Local de nascimento.

Telefone

Endereço.

Bairro.

Cidade

Nome da escola. 


\section{CONTEXTO SÓCIO-AMBIENTAL DE ORIGEM}

Local de nascimento do pai do professor

Idade do pai do professor

Grau de escolaridade do pai do professor.

Profissão/Ocupação do pai do professor

Local de nascimento da mãe do professor.

Idade da mãe do professor..

Grau de escolaridade da mãe do professor.

Profissão/Ocupação da mãe do professor...

Número de irmãos do professor.

Idades dos irmãos do professor.

Grau de escolaridade dos irmãos do professor.

Profissão/Ocupação dos irmãos do professor 


\section{CONTEXTO SÓCIO-AMBIENTAL ATUAL}

Estado civil.

Idade do(a) companheiro(a)

Anos de vida em comum

Local de nascimento do(a) companheiro(a).

Grau de escolaridade do(a) companheiro(a)

Profissão/Ocupação do(a) companheiro(a).

\begin{tabular}{|l|l|l|l|}
\hline Nome dos filhos & $\begin{array}{c}\text { Scxo } \\
\text { dos } \\
\text { filhos }\end{array}$ & $\begin{array}{c}\text { Idadcs } \\
\text { dos } \\
\text { filhos }\end{array}$ & $\begin{array}{l}\text { Grau de } \\
\text { cscolaridadc } \\
\text { locupacão }\end{array}$ \\
\hline & & & \\
\hline & & & \\
\hline & & & \\
\hline & & & \\
\hline & & & \\
\hline & & & \\
\hline
\end{tabular}

Algum filho portador de necessidades especiais? (qual?).

Relacionamento familiar entre as pessoas que participam da familia do professor (marido/mulher/filhos) 
Número de pessoas na casa do professor, que dormem ou participam das despesas da casa

Grau de parentesco

Possui atividades de lazer? (quais)

\section{EXTRATO ECONÔMICO}

Salário do professor.

Salário do pai do professor

Salário da mãe do professor.

Salário do companheiro do professor.

Outras fontes de renda ou de subsídios

Moradia: ( ) própria ( ) alugada ( ) cedida

Número de cômodos. .cozinha(s). banheiros.

Possui automóvel? ( ) $\operatorname{sim} \quad$ ( ) não

Outros bens imóveis (quais) 


\section{PERFIL DO ENTREVISTADO}

Local e ano de formação.

Faculdade

Segundo grau.

Primeiro grau.

Justificativa para ser professor (explicar a escolha profissional).

Anos de magistério

Anos no presente estabelecimento

Classe onde atua

Período

Trabalha em outra escola/emprego/casa (descrever).

Quando tem oportunidade, participa de reciclagens? (Última participação).

Qual o último livro que leu? (relacionado ao trabalho, título e ano) Por que? 


\section{INVESTIGAÇÃO ESPECÍFICA}

Para você, o que é uma criança diferente?

Isso, de você topar com uma criança diferente, já aconteceu?

(fale sobre o fato e quando, mais de uma vez)

O que você fez quando estava diante de uma criança diferente? (você acionou a instituição, falou com a família ou fez um trabalho em classe?)

Qual foi o resultado?

Terapia Ocupacional, você já ouviu falar nisso?

Para que serve a Terapia Ocupacional?

Você já se utilizou dos serviços de um terapeuta ocupacional?

Em relação a uma criança diferente, o que um terapeuta ocupacional poderia fazer para ela?

O que foi mais importante nesta entrevista?(Falar em poucos minutos)

Tempo de entrevista:

Observações (perguntas claras, confusas, se ficou em dúvida ou inseguro) 


\section{ANEXO II}

Manual da Entrevista 


\section{IDENTIFICAÇÃO DO ENTREVISTADO}

Ficha $n^{\circ}$ (identificar o entrevistado)

Data da entrevista (registrar a data)

Nome do professor (identificar o entrevistado)

Data de nascimento (identificar o entrevistado)

Idade (identificar o entrevistado)

Local de nascimento (obter dados do contexto sócio-ambiental do entrevistado)

Telefone (estabelecer comunicação, se necessário)

Endereço (obter dados do contexto sócio-econômico do entrevistado)

Bairro (idem ao item acima)

Cidade (idem ao item acima)

Nome da escola (identificar referência de trabalho do entrevistado) 


\section{CONTEXTO SÓCIO-AMBIENTAL DE ORIGEM}

(Situar o problema, verificando se existe relação entre o contexto sócio-ambiental de origem do professor e percepção do mesmo em reconhecer problemas de aprendizagem e (ou alteração de desenvolvimento)

Local de nascimento do pai do entrevistado (conhecer a procedência da familia do entrevistado

Idade do pai do entrevistado (determinar a faixa etária da familia de origem do entrevistado)

Grau de escolaridade do pai do entrevistado (conhecer a ascendência sócio-ambiental e cultural familiar do entrevistado)

Profissão/Ocupação do pai do entrevistado (conhecer a ascendência sócio-ambiental e cultural-familiar do entrevistado)

Local de nascimento da mãe do entrevistado (conhecer a procedência familiar do entrevistado)

Idade da mãe do entrevistado (determinar a faixa etária da família de origem do entrevistado)

Grau de escolaridade da mãe do entrevistado (conhecer a ascendência sócio-ambiental e cultural- familiar do entrevistado)

Profissão/Ocupação da mãe do entrevistado (conhecer a ascendência sócio-ambiental e cultural-familiar do entrevistado)

Número de irmãos do professor (conhecer a formação/constituição familiar de origem do entrevistado)

Idades dos irmãos do entrevistado (conhecer a faixa etária da formação familiar de origem do entrevistado)

Grau de escolaridade dos irmãos do professor(identificar a situação acadêmica formal dos filhos da familia de origem do entrevistado)

Profissão/Ocupação dos irmãos do professor (identificar as atividades remuneradas exercidas pelos filhos da família de origem do entrevistado) 


\section{CONTEXTO SÓCIO-AMBIENTAL ATUAL}

(Situar o substrato ambiental do professor)

Estado Civil (conhecer a situação de vida do entrevistado)

Idade do companheiro (conhecer a faixa etária do parceiro do entrevistado)

Anos de vida em comum (conhecer aspecto da estabilidade relacional da vida do entrevistado)

Local de nascimento do companheiro (conhecer a origem do parceiro do entrevistado)

Grau de escolaridade do companheiro (conhecer o estatus acadêmico formal do parceiro do entrevistado)

Profissão/Ocupação do companheiro(identificar a atividade remunerada exercida pelo parceiro do entrevistado)

Número/nome dos filhos (conhecer a responsabilidade familiar do entrevistado)

Sexo dos filhos (conhecer a formação da família do entrevistado)

Idades dos filhos (idem ao item acima)

Grau de escolaridade/Ocupação dos filhos (conhecer a responsabilidade e expectativa da família constituida pelo entrevistado)

Algum filho portador de necessidades especiais -qual- (identificar se reconhece algum de seus filhos como uma pessoa diferente)

Relacionamento familiar entre as pessoas que participam da familia do professor (marido/mulher e filhos) (conhecer a dinâmica familiar do entrevistado)

Número de pessoas na casa do professor, que dormem ou participam das despesas da casa (conhecer a condição de vida da família do entrevistado)

Grau de parentesco (conhecer a dinâmica familiar da vida do entrevistado)

Possui atividades de lazer? Que tipo? (conhecer dinâmica da vida do entrevistado) 


\section{EXTRATO ECONÔMICO}

(Explorar o tecido econômico do professor)

Salário do professor (conhecer a "proxis" da condição econômica do entrevistado)

Salário do pai do professor (idem ao item acima)

Salário da mãe do professor (idem ao item acima)

Salário do companheiro do professor (idem ao item acima)

Outras fontes de renda ou de subsidios (idem ao item acima)

Moradia própria? Alugada? Cedida? (idem ao item acima)

Número de cômodos (estabelecer a distribuição do número de pessoas na casa do

entrevistado)

Possui automóvel? (contribuir para identificar aspecto da situação econômica do entrevistado)

Outros bens imóveis (determinar a situação econômica do entrevistado) 


\section{PERFIL DO ENTREVISTADO}

(Observar se a formação/tempo/ e a relação com o trabalho de professor estão relacionados ao re/conhecimento das dificuldades do aluno)

Local e ano de formação (conhecer a origem acadêmica do entrevistado e o tempo de formação)

Faculdade (idem ao descrito acima)

Segundo grau (idem ao descrito acima)

Primeiro grau (idem ao descrito acima)

Justificativa para ser professor (explicar a escolha profissional)

Anos de magistério (saber o tempo que o entrevistado exerce a profissão)

Anos no presente estabelecimento (saber o tempo que o entrevistado trabalha no local da entrevista)

Classe onde atua (identificar o local onde o entrevistado exerce a atividade)

Período (saber em que horário o entrevistado exerce a atividade)

Trabalha em outra escola/emprego (descrever) - (saber se o entrevistado possui outra atividade remunerada ou não) 


\section{AVALIAR O PAPEL DA ATUALIZAÇÃO EM SUBSIDIAR O PROFESSOR PARA CONHECER AS DIFICULDADES DO ALUNO}

Quando tem oportunidade participa de reciclagens? Última participação (identificar o interesse do entrevistado para atualizar-se no trabalho)

Qual o último livro que leu (relacionado ao trabalho, título e ano) Por que? (identificar o interesse do entrevistado para atualizar-se no trabalho) 


\section{INVESTIGAÇÃO ESPECÍFICA}

(Investigar qual é a percepção do professor na deteç̧ão de problemas de aprendizagem/desenvolvimento dos alunos)

Para você, o que é uma criança diferente? (determinar a condição do professor em reconhecer problemas)

Isso de você topar com uma criança diferente, já aconteceu? (determinar a condição do professor em reconhecer problemas)

O que você fez? Você acionou a instituição, falou com a familia ou fez um em classe? (estabelecer qual foi a atitude frente ao problema)

Qual foi o resultado? (identificar as conseqüências da ação do professor)

Terapia ocupacional, você já ouviu falar nisso? (identificar a familiaridade do professor com a terapia ocupacional)

Você já se utilizou dos serviços de um terapeuta ocupacional? (identificar se o professor conhece o trabalho do terapeuta ocupacional)

Em relação a uma criança diferente, o que o terapeuta ocupacional poderia fazer para ela? (idem acima)

Para você o que foi mais importante nesta entrevista? (re-editar de forma sucinta o aspecto considerado mais significativo pelo entrevistado) 
ANEXO III

Ficha da Escola 


\section{IDENTIFICAÇÃO DA ESCOLA}

Escola ${ }^{\circ}$

Data

Nome da escola.

Endereço da escola

Telefone da escola

Nome do diretor.

Idade do diretor

Anos de magistério

Anos no cargo

Número de alunos da escola

Número de professores da escola

Número de outros servidores da escola

Número de classes da escola

Período de funcionamento da escola 


\section{ANEXO IV}

Manual da Ficha da Escola 
Folha de Referência da Página de Rosto do Formulário da Pesquisa "Capacidade Diagnóstica do Professor de Educação Infantil e Familiaridade com a Terapia Ocupacional

Escola $n^{\circ}$ (controle interno)

Data da entrevista (registrar o momento da entrevista)

Nome da escola (identificar o estabelecimento)

Endereço da escola (registrar referência local do estabelecimento)

Telefone da escola (referência complementar)

Nome do diretor (identificar o gerente do estabelecimento)

Idade do diretor (conhecer a faixa etária do gerente)

Anos de magistério (conhecer tempo de trabalho do gerente)

Anos no cargo (conhecer tempo de trabalho do gerente no presente estabelecimento)

Número de alunos da escola (conhecer a população do estabelecimento)

Número de professores da escola (conhecer a população da escola )

Número de outros servidores da escola (conhecer a população da escola)

Número de classes da escola (conhecer a distribuição da escola)

Período de funcionamento da escola (conhecer a rotina da escola) 
ANEXO V

Termo de Consentimento 


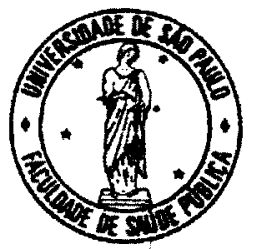

\section{TERMO DE CONSENTIMENTO}

Título da pesquisa: Capacidade diagnóstica do professor de escola infantil e familiaridade com a Terapia Ocupacional

A pesquisa que vamos realizar far parte da lese de doutoramento da aluna Maria Cecilia Lcile de Moracs do Curso de Pós-Graduação da Faculdade de Saúdc Púbtica da Universidade de São Paulo. Para tanto, cstamos solicitando a sua importante colaboraçào. a fim de responder algumas perguntas a respcito da capacidade de observação do professor de cscola infantil c a fantiliaridade, do mesmo, no quc diy respcito a profissão de Tcrapia Ocupacional. Esta pesquisa ć muito importantc para que as pessoas, cspccialistas ou não do assunto, tenham um olhar mais critico sobrc csıc tcma.

$\mathrm{O}$ depoimento que o Sr. nos fornecera, nos ajudará a compreender melhor a posição e atuação do professor da escola infantil frente a algumas situações e a partir destas, permitir algumas propostas de ações no âmbito da saúde dentro do contexto da escola.

As cstatísticas cm geral, como são aprescntadas, são frias, rcferindo-sc às pessoas como númcros, c o que a gente quer ć dar vida a csses números, a partir de scu rclalo.

Solicitamos que o Sr. participe da entrevista que vai ocupar um pouco do seu tempo, comprometendo-nos a não divulgar scu nome c nem o que nos vai contar. Promctemos, lambém, que, logo que icrminarmos nosso trabalho, vamos retornar para o Sr. a síntesc do que escrevemos. Asscguramos, rcalçadamentc, que sua participação ć livec c voluntária, scndo quc, a qualquer momento da cnircvista.o Sr. podcrá desistîr c que desistência não implicará cm quaisquer riscos c desconfortos futuros.

Com o compromisso de acompanhar todo o processo da entrevista, colocamo-nos à disposição para esclarecimentos, seja do modo como vamos trabalhar, seja do conteúdo e dos objetivos da pesquisa. Esta pesquisa não implica em despesas da parte do entrevistado.

Dcsde já, agradcccmos a sua valiosa colaboraçào.

São Paulo, de de 2002

Maria Cccilia Lcitc dc Moracs

Nome do entrevistado

RG 8537725.9

Endcreço Av. Dr. Arnaldo $715,2^{\circ}$ andar

e mail: mcecilmoraes(ajig.com.br 
ANEXO VI

Autorização para Acesso aos Professores 
São Paulo, ..... de de

De: Prof. Dr. Paulo Rogério Gallo

Para:

$\mathrm{A} / \mathrm{C}$

Prezados(as) Senhores(as)

Venho através deste solicitar sua autorização para que minha orientanda Maria Cecília Leite de Moraes, aluna da Faculdade de Saúde Pública da Universidade de São Paulo, nivel de doutorado, possa proceder parte de seu trabalho de pesquisa neste estabelecimento. Os procedimentos serão informados, pessoalmente, pela aluna, porém, posso adiantar, que se trata de entrevistas diretas com V. Sa. e com alguns professores da instituição.

Certo, desde já, de poder contar com sua valiosa colaboração, subscrevo-me, atenciosamente,

Prof. Dr. Paulo Rogério Gallo

Depto de Saúde Materno Infantil

Faculdade de Saúde Pública da USP

e mail: prgalloa ausp.br 
ANEXO VII

Termo de Compromisso Ético 


\section{TERMO DE COMPROMIISSO ÉTICO}

Declaro, para os devidos fins, que as informações colhidas durante a entrevista serão usadas sem que o respondente e o estabelecimento, ao qual o mesmo pertença, sejam identificados. Todas as declarações serão usadas somente para fins de pesquisa sendo que a divulgação da transcrição de parte ou todo, das opiniões gravadas, serão usados dentro do contexto da investigação.

São Paulo, de. de. 